\title{
Doppler and Duplex Sonography for the Diagnosis of the Irreversible Cessation of Brain Function ("Brain Death"): Current Guidelines in Germany and Neighboring Countries
}

Authors

Affiliations

\author{
U. Walter ${ }^{1}$, S. J. Schreiber ${ }^{2}$, M. Kaps ${ }^{3}$
}

Department of Neurology, University of Rostock, Rostock, Germany

2 Department of Neurology, Asklepios Hospital Brandenburg, Brandenburg an der Havel, Germany

Department of Neurology, Justus-Liebig University, Giessen, Germany

\section{VNR 2760512017152371045}

received 21.5.2016

accepted 28.6.2016

Bibliography

Dol http://dx.doi.org/

10.1055/s-0042-112222

Published online:

August 31, 2016

Ultraschall in Med 2016; 37: 558-578 @ Georg Thieme Verlag KG Stuttgart · New York . ISSN 0172-4614

\section{Correspondence \\ Prof. Uwe Walter}

Department of Neurology, University of Rostock

Gehlsheimer Str. 20

18147 Rostock

Germany

Tel.: ++ 49/38174949696

Fax: ++ 49/3 81/4944794

uwe.walter@med.uni-rostock. de

License terms

(c) $(1) \risingdotseq$

\section{Abstract}

\section{$\nabla$}

Extra- and transcranial sonography of brain-supplying arteries is accepted worldwide in brain death protocols as a valid "ancillary" method of proving brain circulatory arrest. Color-coded duplex sonography and CT angiography have been newly incorporated in the fourth update of the German Medical Association's guidelines for the determination of the irreversible cessation of brain function ("brain death"), effective July 2015. The updated guidelines address in more detail the diagnostic procedures and the required qualifications of the examiners. The present article summarizes the guidelines and the recommendations regarding the application and documentation of ultrasound findings for the diagnosis of brain circulatory arrest in children and adults, as valid in Germany. The method, limitations, and procedure in the case of inconclusive findings are described. Age-related minimum values of mean arterial pressure for the diagnosis of cerebral circulatory arrest in children are presented. A concise overview of the respective regulations for the use of sonography for diagnosing brain death in other countries, especially in the countries neighboring Germany, is given.

\section{Introduction}

$\nabla$

One of the main updates in the fourth edition of the German Medical Association's guidelines for the determination of the irreversible cessation of brain function ("brain death") in Germany is the inclusion of duplex sonography and computed tomography angiography (CTA) as methods for determining cerebral circulatory arrest [1]. Moreover, detailed definitions that are further explained in the appendix "Justifications" particularly for neurosonology are included. The following explanations are based in part on a recent overview [2] and refer to the original text of the guidelines (framed with quotation marks) and the recommendations of the German Society for Clinical Neurophysiology and Functional Imaging for the diagnosis of irreversible cessation of brain function $[1,3]$. To provide readers with a quick overview, new content of the guidelines is indicated and commentated.

\section{Comparison with the guidelines of other countries \\ $\nabla$}

After electroencephalography, transcranial Doppler sonography (TCD) and transcranial colorcoded duplex sonography (TCCS) are the most commonly used ancillary methods worldwide and regardless of geographical region. TCD is even mandatory in $5 \%$ of countries but is used optionally in the USA [4]. However, sonography is not specified in the legal regulations of some European countries for the determination of cerebral circulatory arrest, e.g., in France, Denmark, and Sweden [5-8], even though it is sometimes used there as a preliminary examination prior to more invasive testing $[7,8]$. In Germany as well as internationally, TCD is the most frequently used method for determining cerebral circulatory arrest, ahead of CTA and selective arterial catheter angiography depending on country-specific guidelines [4, 8-13]. In any case, selective arterial catheter angiography is only rarely applicable in Germany for diagnosing brain death, i.e., only when performed to determine the type of brain damage or for making treatment decisions and when it could provide consequential therapeutic information [1]. The national recommendations largely coincide with respect to the technical parameters and the pathognomonic sonographic findings of circulatory arrest (systolic spikes, biphasic flow signals) but differ in some cases with respect to the minimum number of vessels to be examined $[1-3,12,14-22]$ ( $\bullet$ Table 1$)$. For example, TCD of only the bilateral middle cere- 


\section{Doppler- und Duplexsonografie in der Diagnostik Aktuelle Richtlinien in Deutschland und benachbarten Ländern} des irreversiblen Hirnfunktionsausfalls („Hirntod“):

\section{Zusammenfassung \\ $\nabla$}

Die extra- und transkranielle Sonografie der hirnversorgenden Arterien ist weltweit anerkannt als apparative Zusatzdiagnostik zur Feststellung des zerebralen Zirkulationsstillstands, wie er für den irreversiblen Hirnfunktionsausfall charakteristisch ist. In Deutschland haben in die vierte Fortschreibung der Richtlinie der Bundesärztekammer zur Feststellung des irreversiblen Hirnfunktionsausfalls („Hirntod“), gültig seit Juli 2015, auch die farbkodierte Duplexsonografie und die CT-Angiografie Eingang gefunden. Deutlich ausführlicher und präziser werden formale und praktische Ausführungsbestimmungen formuliert, und es werden höhere Anforderungen an die Qualifikation der Untersucher gestellt. Dieser Artikel stellt die in Deutschland geltenden Richtlinien und Empfehlungen zum Einsatz und zur Befunddokumentation sonografischer Verfahren in der Diagnostik des zerebralen Zirkulationsstillstands bei Kindern und Erwachsenen dar. Methodik, Limitationen und Vorgehen bei unsicheren Befunden der Sonografie werden beschrieben. Altersbezogene Mindestgrößen des arteriellen Mitteldruckes zur Diagnostik des zerebralen Zirkulationsstillstands bei Kindern werden vorgestellt. Es wird ein Überblick über die in anderen Ländern, speziell in den Nachbarländern Deutschlands, geltenden Regularien zum Einsatz der Sonografie in der Hirntoddiagnostik gegeben.

\section{Einleitung}

In Deutschland ist eine der wesentlichen Neuerungen der aktuellen vierten Fortschreibung der Richtlinie der Bundesärztekammer zur Feststellung des irreversiblen Hirnfunktionsausfalls („Hirntod“) im folgenden Text mit RL4-BÄK bezeichnet - die Aufnahme der Duplexsonografie und der computertomografischen Angiografie (CTA) als Nachweisverfahren für den zerebralen Zirkulationsstillstand
[1]. Außerdem wurden in der RL4-BÄK umfangreiche Präzisierungen vorgenommen, die in den dort separat angefügten „Begründungen“ insbesondere auch für die Neurosonologie noch weiter erläutert sind. Die folgenden Ausführungen basieren teilweise auf einer kürzlichen Übersichtsarbeit [2] und nehmen Bezug auf den zitatweise in Anführungszeichen gesetzten Originaltext der RL4-BÄK sowie die Empfehlungen der Deutschen Gesellschaft für Klinische Neurophysiologie und Funktionelle Bildgebung (DGKN) zur Diagnostik des irreversiblen Hirnfunktionsausfalls [1, 3]. Um dem Leser einen schnellen Überblick zu gewähren, werden neue Inhalte der RL4-BÄK im Text besonders gekennzeichnet und kommentiert. Aus Gründen der Lesbarkeit wird darauf verzichtet, geschlechtsspezifische Formulierungen zu verwenden. Soweit personenbezogene Bezeichnungen nur in männlicher Form angeführt sind, beziehen sie sich auf Männer und Frauen in gleicher Weise.

\section{Vergleich mit den Richtlinien anderer Länder \\ $\nabla$}

Weltweit und unabhängig von der geografischen Region ist die transkranielle Dopplersonografie (TCD) bzw. transkranielle farbkodierte Duplexsonografie (TCCS) nach der Elektroenzephalografie die am häufigsten angewendete apparative Zusatzuntersuchung; in $5 \%$ der Länder ist die TCD sogar verbindlich vorgeschrieben, während sie in den USA nur optional eingesetzt wird [4]. In den gesetzlichen Regularien einiger europäischer Länder ist die Sonografie allerdings nicht zur Feststellung des zerebralen Zirkulationsstillstands vorgesehen, z.B. in Frankreich, Dänemark und Schweden [58], wenngleich sie auch dort gelegentlich als Voruntersuchung vor invasiveren Untersuchungen zum Einsatz kommt [7, 8]. In Deutschland und auch international ist die TCD das am häufigsten eingesetzte Verfahren zur Feststellung des zerebra- 
Table 1 Value of Doppler and duplex sonography for the determination of cerebral circulatory arrest as part of the determination of brain death in Germany and in neighboring countries.

\begin{tabular}{|c|c|c|}
\hline country [reference] & ultrasound modality & vessels to be investigated ${ }^{1}$ \\
\hline Austria [18] & TCD $(+\mathrm{ECD})$ or ECCS & ec: ICA ${ }^{2}, V^{2}$; ic: ICA, MCA, VA, BA \\
\hline Belgium [15] & TCD or TCCS ${ }^{3}$ & not specified \\
\hline Czech Republic [22] & TCD or TCCS & ic: ICA, MCA, VA, BA ${ }^{4}$ \\
\hline Denmark [5] & not accredited & \\
\hline France $[7,8]$ & not accredited ${ }^{5}$ & (ec: ICA, VA; ic: MCA, BA) \\
\hline Germany [1] & $\begin{array}{l}E C D+T C D \text { or TCCS } \\
\text { (or ECCS) }\end{array}$ & ec: ICA ${ }^{6}, V^{6} ;$ ic: ICA, MCA, VA $A^{6}, B^{6}$ \\
\hline Luxembourg [16] & TCD & not specified \\
\hline Poland [19] & TCD & ic: MCA, BA ${ }^{4}$ \\
\hline Sweden [6] & not accredited & \\
\hline Switzerland [20] & $\mathrm{ECCS}+\mathrm{TCCS}$ & ec: ICA; ic: MCA \\
\hline The Netherlands [17] & TCD or TCCS (or ECCS) & ec: ICA, VA ${ }^{7}$; ic: MCA, BA \\
\hline
\end{tabular}

BA: basilar artery; ICA: internal carotid artery; MCA: middle cerebral artery; VA: vertebral artery; ec: extracranial; ECCS: extracranial color-coded duplex sonography; ECD: extracranial Doppler sonography; ic: intracranial; TCCS: transcranial color-coded duplex sonography; TCD: transcranial Doppler sonography.

${ }^{1}$ twin arteries are to be documented bilaterally, unless otherwise noted.

2 ECD of the relevant artery if this artery could not be visualized with TCD or, alternatively, investigation of both extracranial ICA and VA if only ECCS is performed.

3 unlike TCD, TCCS is not explicitly listed [15] but is implicitly approved (personal communication of Dr. Françoise van de Wyngaert, Brussels, Belgium).

${ }^{4}$ at least these intracranial arteries are to be documented.

${ }^{5}$ some experts recommend performing ECD+TCD optionally to shorten the obligatory waiting period (6h) between clinical investigation and CT angiography [8].

${ }^{6}$ depending on the ultrasound modality, i. e. ECD+TCD or TCCS, different vessel segments are to be documented (for details, see Table 3 ); if the intracranial vessels cannot be visualized, ECD or ECCS of both ICA and VA can be performed as an alternative.

7 examination of extracranial vessels if not all 3 intracranial arteries (bilateral MCA, BA) are visualized with TCD or TCCS. tions in which the apnea test or examination of individual brain stem reflexes cannot be performed or there is uncertainty about the effect of CNS depressants on the clinical symptoms of brain death despite compliance with strict rules $[1,4,10,12]$. TCCS of the basal brain arteries is explicitly included in the Latin American, German, Dutch, Swiss, and Czech guidelines as a method for detecting cerebral circulatory arrest [1, 12, 17, 20, 22]. Dilation of the optical nerve sheath due to increased intracranial pressure can be detected using transorbital B-mode ultrasound but does not provide a reliable diagnosis of irreversible cessation of brain function and is therefore not suitable as an ancillary method for diagnosing brain death [23]. Therefore, it will not play a role in international brain death protocols in the future.

\section{Use of Doppler/duplex sonography $\nabla$}

Doppler/duplex sonography can be used in all types of brain damage and at every age to detect cerebral circulatory arrest [3, 14, 24 - 30]. "If cerebral circulatory arrest is detected, potentially reversible causes of the clinical symptoms of the cessation of brain function are ruled out and the irreversibility of the cessation of brain function can be determined without a waiting period and clinical follow-up examinations in adults and children after the end of the second year of life" [1]. In children who have not yet completed their second year of life, Doppler/duplex sonography can also be used to prove irreversibility but must be performed after each of the two clinical examinations [1]. "A prerequisite for the use of this method is a sufficient age-appropriate mean arterial pressure that must be more than $60 \mathrm{mmHg}$ in adults" [1]. A sufficient mean arterial pressure must also be present in children. However, this value can be lower depending on age, height, and weight ( Table 2) [31, 32]. Compared to other methods for determining cerebral circulatory arrest, Doppler/duplex sonography has the following advantages: able to be used at any age, faster recording of findings, lower costs, and avoidance of potentially nephrotoxic X-ray contrast agents which can be relevant in the case of possible organ donation $[33,34]$.

bral artery and the basilar artery is required in Holland, Poland, and Latin America [12, 17, 19] in agreement with the recommendation of a North American group of experts [13], while bilateral examination of the middle cerebral artery, internal carotid artery, and vertebral artery is required in Germany, Austria, the Czech Republic, and Japan (with additional examination of the basilar artery being required in the Czech Republic) [1, 14, 18, 22]. In concordance with the German guidelines, the particular importance of TCD or TCCS is highlighted in the guidelines of most countries in situa-

\section{Pathophysiology and limitations of the method \\ $\nabla$}

The characteristic Doppler/duplex sonographic signals of cerebral circulatory arrest are the result of a pathological increase in intracranial pressure above the mean arterial pressure ( $\bullet$ Fig. 1 ) [35]. Careful monitoring of ventilated intensive care patients with severe brain damage already entails regular transcranial Doppler or color duplex sonographic examinations, making it possible to 
len Zirkulationsstillstands, je nach länderspezifischen Richtlinien vor der CTA und der selektiven arteriellen Katheter-Angiografie [4, 8-13]. Die selektive arterielle Katheter-Angiografie ist in Deutschland ohnehin nur selten in der Hirntoddiagnostik anwendbar, nämlich nur dann, wenn die Untersuchung zur Klärung der Art der Hirnschädigung oder zur Therapieentscheidung durchgeführt wird und sie die Möglichkeit therapeutischer Konsequenzen bietet [1]. Die nationalen Empfehlungen stimmen weitgehend überein im Hinblick auf die technischen Parameter und die pathognomonischen sonografischen Befunde des Zirkulationsstillstands (systolische Spitzen, biphasische Strömungssignale), unterscheiden sich aber teilweise in der Festlegung der Anzahl der minimal zu untersuchenden Gefäße [1-3, 12, 14-22] (৫ Tab. 1). Beispielsweise wird in den Niederlanden, in Polen und in Lateinamerika die TCD nur der beiderseitigen A. cerebri media und der A. basilaris gefordert $[12,17,19]$, in Übereinstimmung mit der Empfehlung einer nordamerikanischen Expertengruppe [13], während in Deutschland, Österreich, der Tschechischen Republik und Japan die Untersuchung der beiderseitigen $A$. cerebri media, der beiderseitigen $A$. carotis interna sowie der beiderseitigen A. vertebralis gefordert wird (in der Tschechischen Republik zusätzlich der A. basilaris) [1, 14, 18, 22]. Übereinstimmend mit den deutschen Richtlinien wird die besondere Bedeutung der TCD bzw. TCCS in den Richtlinien der meisten Länder hervorgehoben in Situationen, in denen der Apnoe-Test oder die Untersuchung einzelner Hirnstammreflexe nicht durchgeführt werden kann oder trotz Einhaltung strenger Regeln Unsicherheit bezüglich der Wirkung zentral dämpfender Medikamente auf die klinischen Symptome des Hirnfunktionsausfalls besteht $[1,4,10,12]$. Die explizite Aufnahme der TCCS der Hirnbasisarterien als Verfahren zum Nachweis des zerebralen Zirkulationsstillstands ist den lateinamerikanischen, deutschen, niederländischen, schweizerischen und tschechischen Richtlinien gemeinsam [1, 12, 17, 20, 22]. Mittels transorbitaler B-Bild-Sonografie kann eine Erweiterung der Scheide des Nervus opticus infolge des erhöhten Hirndrucks detektiert werden, sie erlaubt jedoch keine sichere Diagnose des irreversiblen Hirnfunktionsausfalls und ist daher als Zusatzverfahren in der Hirntoddiagnostik ungeeignet [23]; sie wird somit in den internationalen Hirntodprotokollen auch künftig keine Rolle spielen.

\section{Einsatz der Doppler-|Duplexsonografie}

Die Doppler- bzw. Duplexsonografie kann bei allen Hirnschädigungen und in jedem Lebensalter zum Nachweis des zerebralen Zirkulationsstillstands eingesetzt werden [3, 14, 24-30]. „Beim Nachweis des zerebralen Zirkulationsstillstands sind potenziell reversible Ursachen der klinischen Symptome
Tab. 1 Stellenwert der Doppler-/Duplexsonografie zum Nachweis des zerebralen Zirkulationsstillstands im Rahmen der Hirntodfeststellung in Deutschland und benachbarten Ländern.

\begin{tabular}{|c|c|c|}
\hline Land [Referenz] & Ultraschall-Modalität & Darzustellende Gefäße ${ }^{1}$ \\
\hline Belgien [15] & TCD oder TCCS ${ }^{2}$ & nicht spezifiziert \\
\hline Dänemark [5] & nicht zugelassen & \\
\hline Deutschland [1] & $\begin{array}{l}\text { ECD +TCD oder TCCS } \\
\text { (oder ECCS) }\end{array}$ & ec: $\mathrm{ACl}^{3}, \mathrm{AV}^{3} ; \mathrm{ic}: \mathrm{ACl}, \mathrm{ACM} \mathrm{AV}^{3}, \mathrm{AB}^{3}$ \\
\hline Frankreich $[7,8]$ & nicht zugelassen ${ }^{4}$ & (ec: $A C l, A V ;$ ic: $A C M, A B)$ \\
\hline Luxemburg [16] & $\mathrm{TCD}$ & nicht spezifiziert \\
\hline Niederlande [17] & $\begin{array}{l}\text { TCD oder TCCS (oder } \\
\text { ECCS) }\end{array}$ & ec: $A C l, A V^{5}$; ic: $A C M, A B$ \\
\hline Österreich [18] & TCD (+ECD) oder ECCS & ec: $\mathrm{ACl}^{6}, \mathrm{AV}^{6}$; ic: $\mathrm{ACl}, \mathrm{ACM}, \mathrm{AV}, \mathrm{AB}$ \\
\hline Polen [19] & TCD & ic: $A C M, A B^{7}$ \\
\hline Schweden [6] & nicht zugelassen & \\
\hline Schweiz [20] & ECCS+TCCS & ec: ACl; ic: ACM \\
\hline Tschechische R. [22] & TCD oder TCCS & ic: $\mathrm{ACl}, \mathrm{ACM}, \mathrm{AV}, \mathrm{AB}^{7}$ \\
\hline
\end{tabular}

AB: A. basilaris; ACI: A. carotis interna; ACM: A. cerebri media; AV: A. vertebralis; ec: extrakraniell; ECCS: extrakranielle farbkodierte Duplexsonografie; ECD: extrakranielle Dopplersonografie; ic: intrakraniell; TCCS: transkranielle farbkodierte Duplexsonografie; TCD: transkranielle Dopplersonografie.

1 Paarige Arterien sind beidseitig zu dokumentieren, wenn nicht anders angegeben.

${ }^{2}$ Im Unterschied zur TCD ist die TCCS nicht ausdrücklich gelistet [15], jedoch implizit zugelassen (persönliche Mitteilung von Dr. Françoise van de Wyngaert, Brüssel, Belgien).

3 Je nach Einsatz von ECD+TCD oder TCCS sind unterschiedliche Gefäßsegmente zu dokumentieren (für Details siehe Tab.3); wenn die intrakraniellen Gefäße nicht darstellbar sind, kann alternativ die ECD bzw. ECCS von $\mathrm{ACl}$ und $\mathrm{AV}$ erfolgen.

${ }^{4}$ Von einigen Experten wird die ECD+TCD optional empfohlen zur Verkürzung der obligatorischen Wartezeit (6h) zwischen klinischer Untersuchung und CT-Angiografie [8].

${ }^{5}$ Untersuchung der extrakraniellen Gefäße, wenn nicht alle 3 intrakraniellen Gefäße (ACM bds., AB) mit TCD bzw. TCCS darstellbar sind.

${ }^{6}$ ECD des jeweiligen Gefäßes, wenn dieses mit TCD intrakraniell nicht darstellbar ist, bzw. Untersuchung von extrakranieller $\mathrm{ACl}$ und $\mathrm{AV}$, falls nur die ECCS durchgeführt wird.

${ }^{7}$ Diese intrakraniellen Gefäße müssen mindestens dokumentiert sein.

Tab. 2 Altersabhängige Mindestwerte des arteriellen Mitteldrucks für die Durchführung der Doppler-/Duplexsonografie zum Nachweis des zerebralen Zirkulationsstillstands.

\begin{tabular}{|c|c|}
\hline $\begin{array}{l}\text { Alter } \\
\text { [Jahre] }\end{array}$ & $\begin{array}{l}\text { Mindestwert des arter- } \\
\text { iellen Mitteldrucks }{ }^{1} \\
{[\mathrm{mmHg}}\end{array}$ \\
\hline 1 & $>35$ \\
\hline 2 & $>40$ \\
\hline $3-4$ & $>45$ \\
\hline $5-7$ & $>50$ \\
\hline $8-10$ & $>55$ \\
\hline$>10$ & $>60$ \\
\hline
\end{tabular}

${ }^{1}$ Diese Werte entsprechen näherungsweise den publizierten $5 \%$ Perzentilen des arteriellen Mitteldrucks bei Kindern mit mittlerer Körpergröße der jeweiligen Altersgruppe (jeweils mittlerer der geschlechtsspezifisch angegebenen Werte des arteriellen Mitteldruckes) [31]; wenn die Körpergröße eines Kindes deutlich von seiner Altersnorm abweicht, sollte der individuelle Richtwert einer differenzierteren Tabelle entnommen werden [31].

des Hirnfunktionsausfalls ausgeschlossen und es kann die Irreversibilität des Hirnfunktionsausfalls bei Erwachsenen und Kindern ab dem vollendeten 2. Lebensjahr ohne Wartezeit und klinische Verlaufsuntersuchungen festgestellt werden“ [1]. Bei Kindern in einem Alter unterhalb des vollendeten 2. Lebensjahres kann die Doppler-/Duplexsonografie ebenfalls zum Irreversibilitätsnachweis eingesetzt werden, muss dann aber nach jeder der beiden klinischen Untersuchungen durchgeführt werden [1]. „Voraussetzung für den Einsatz dieser

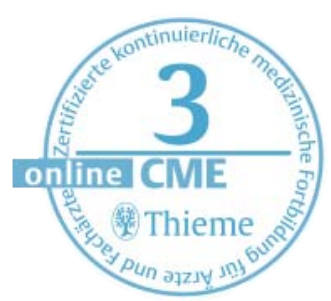


Fig. 1 Time course of increase of intracranial pressure (ICP). Shown is the Doppler wave frequency spectrum of middle cerebral artery over time with increasing ICP. The diastolic flow component diminishes when the ICP becomes larger than the diastolic arterial blood pressure. Biphasic flow signals indicate cerebral circulatory arrest if there is no remaining net flow in the forward direction [35].

Abb. 1 Zeitliche Dynamik der intrakraniellen Drucksteigerung. Dopplerfrequenzspektrum abgeleitet aus der $A$. cerebri media im zeitlichen Verlauf. Die diastolische Strömungskomponente verschwindet, wenn der intrakranielle Druck den diastolischen Blutdruck übersteigt. Biphasische Strömungssignale signalisieren den zerebralen Zirkulationsstillstand, wenn kein Netto-Vorwärts-Fluss mehr vorliegt [35].

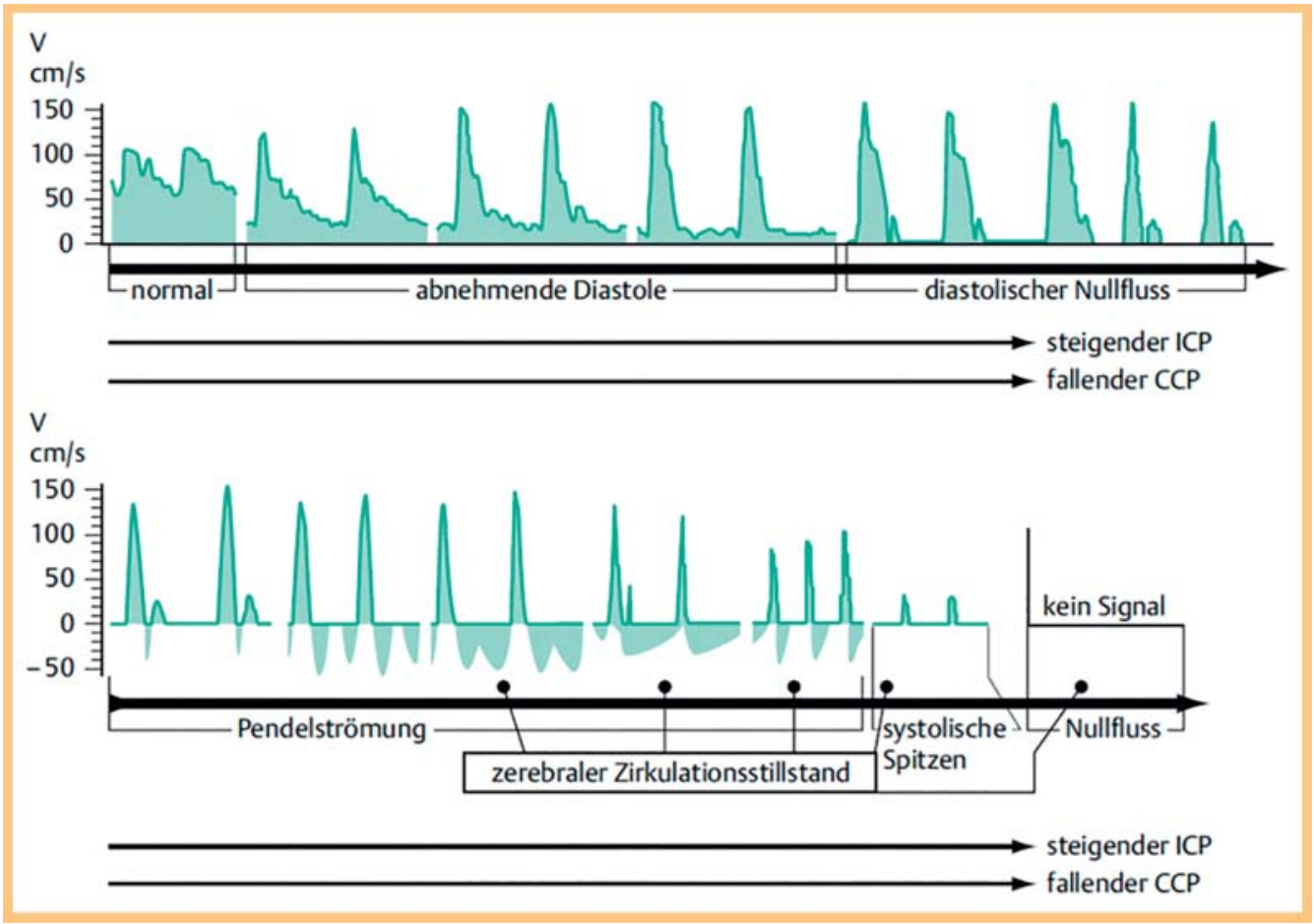

track whether and how the typical finding of irreversible cerebral circulatory arrest develops. Sonography has special diagnostic value particularly here. In addition, a time dependence of the development of the characteristic Doppler/duplex sonographic signals even after determination of the clinical symptoms of the cessation of brain function has been described and has a potential effect on the sensitivity of sonography. Exemplarily, cerebral circulatory arrest has been detected via TCD in only $58 \%$ of cases up to 6 hours after clinical diagnosis but is detected in $77 \%, 83 \%$ and $100 \%$ of cases after $6-12 \mathrm{~h}, 12-24 \mathrm{~h}$, and $24-36 \mathrm{~h}$, respectively [36]. "Following open craniocerebral trauma and decompression craniotomy, regionally limited cerebral circulation, e.g., as a result of spontaneous extra-intracranial anastomosis, can occur so that cerebral circulatory arrest cannot be diagnosed by Doppler/duplex sonography of the basal brain arteries and must be detected by other perfusion examinations" [1]. "After severe open craniocerebral trauma and in individual cases of secondary brain injury, cerebral circulatory arrest does not occur when the intracranial pressure cannot increase above the mean arterial pressure" [1]. This situation can occur in newborns and children prior to the end of the second year of life even without cranial injury since the cranial sutures and fontanelles do not close until the end of the second year of life $[1,14]$. In these cases the irreversibility of the cessation of brain function must be determined under consideration of age and the type of brain injury by clinical follow-up examinations after the standard wait times or on the basis of suitable electrophysiological findings $[1,3]$.
A further major limitation of TCD and TCCS is the dependence of the signal quality on the size and location of the transtemporal bone window ("acoustic window") that limits the examination of intracranial arteries or makes examination impossible particularly in older patients $[37,38]$. In this case (and only this case), the German guidelines state that bilateral examination of the extracranial arteries (internal carotid artery and vertebral artery) is sufficient [1].

\section{Special features of Doppler and duplex sonography \\ $\nabla$}

"In contrast to Doppler sonography, transcranial duplex sonography makes it possible to detect the penetration of ultrasound through the cranial bone and to determine the location of the intracranial arteries regardless of the presence of blood flow in these arteries by visualizing the brain tissue surrounding the intracranial arteries" [1]. "Signal-enhancing ultrasound contrast agents increase the sensitivity of duplex sonography to detect the flow signals in the intracranial arteries that are characteristic for cerebral circulatory arrest" $[1,39,40]$. In Germany, only the ultrasound contrast agent SonoVue ${ }^{\circledR}$ (Bracco Imaging Deutschland) is approved for contrast-enhanced ultrasound (CEUS) in cases in which ultrasound examination without contrast agent is not diagnostic. Refer to earlier studies for details regarding CEUS [39-41]. The segments of the internal carotid artery and the vertebral artery to be visualized differ in some respects for Doppler sonography and duplex sonography in the guidelines 
Methode ist ein altersentsprechend suffizienter arterieller Mitteldruck, der bei Erwachsenen mehr als $60 \mathrm{mmHg}$ betragen muss" [1]. Bei Kindern muss ebenfalls ein suffizienter arterieller Mitteldruck vorliegen, der jedoch in Abhängigkeit von Alter und Körpergröße kleinere Werte annehmen kann (४ Tab. 2) [31, 32]. Gegenüber anderen Verfahren zur Feststellung des zerebralen Zirkulationsstillstands hat die Doppler-/Duplexsonografie die Vorteile der Anwendbarkeit in jedem Lebensalter, der schnelleren Befunderhebung, der geringeren Kosten und nicht zuletzt der Vermeidung potenziell nephrotoxischer Röntgenkontrastmittel, was im Falle einer möglichen Organspende relevant sein kann $[33,34]$.

\section{Pathophysiologie und methodische Limitationen \\ $\nabla$}

Die charakteristischen doppler-/duplexsonografischen Signale eines zerebralen Zirkulationsstillstands sind Folge eines pathologischen Anstiegs des intrakraniellen Drucks über den arteriellen Mitteldruck ( $\boldsymbol{\Theta}$ Abb. 1) [35]. Sorgfältiges Monitoring von beatmeten Intensivpatienten mit schweren Hirnschädigungen schließt ohnehin regelmäßige transkranielle doppler- oder farbduplexsonografische Untersuchungen ein, so dass verfolgt werden kann, ob und wie sich der typische Befund des irreversiblen zerebralen Zirkulationsstillstands allmählich entwickelt. Speziell hierin liegt ein besonderer diagnostischer Wert der Sonografie. Es wurde zudem eine Zeitabhängigkeit der Entwicklung der charakteristischen doppler-/duplexsonografischen Signale auch nach Feststellung der klinischen Symptome des Hirnfunktionsausfalls beschrieben, was einen potenziellen Einfluss auf die Sensitivität der Sonografie hat. So wurde bis zu $6 \mathrm{~h}$ nach der klinischen Diagnose der zerebrale Zirkulationsstillstand mittels TCD nur in $58 \%$ der Fälle, jedoch nach 6-12h, 12-24h bzw. 24$36 \mathrm{~h}$ in $77 \%, 83 \%$ bzw. $100 \%$ nachgewiesen [36]. „Nach offenen Schädel-Hirn-Verletzungen und nach Dekompressionskraniotomien kann eine regional begrenzte zerebrale Zirkulation, z.B. infolge spontaner extra-intrakranieller Anastomosen, auftreten, so dass der zerebrale Zirkulationsstillstand durch die Doppler-/Duplexsonografie der Hirnbasisarterien nicht diagnostiziert werden kann und durch andere Perfusionsuntersuchungen nachzuweisen ist“ " 11]. „Nach großen offenen Schädel-Hirn-Verletzungen und vereinzelt bei sekundären Hirnschädigungen kommt es, wenn der intrakranielle Druck nicht über den mittleren arteriellen Druck ansteigen kann, nicht zu einem zerebralen Zirkulationsstillstand“ [1]. Diese Situation kann auch ohne Schädelverletzung bei Neugeborenen und bei Kindern bis zum vollendeten 2 . Lebensjahr vorliegen, da sich die Schädelnähte und die Fonta- nellen erst im 2. Lebensjahr vollständig verschließen [1, 14]. In diesen Fällen ist die Irreversibilität des Hirnfunktionsausfalls unter Berücksichtigung des Alters und der Art der Hirnschädigung durch klinische Verlaufsuntersuchungen nach den normierten Wartezeiten oder durch geeignete elektrophysiologische Befunde nachzuweisen $[1,3]$.

Eine weitere wesentliche Limitation der TCD und TCCS ist die Abhängigkeit der Signalqualität von der Größe und Lage des transtemporalen Knochenfensters („Schallfensters“), die insbesondere bei älteren Patienten die Untersuchung intrakranieller Arterien einschränken oder unmöglich machen kann $[37,38]$. Für diesen Fall (und nur für diesen Fall) sieht die RL4-BÄK allerdings die Möglichkeit der Untersuchung der beiderseitigen extrakraniellen Arterien (A. carotis interna und A. vertebralis) als ausreichend vor [1].

\section{Besonderheiten der Doppler- und der Duplexsonografie \\ $\nabla$}

„Im Gegensatz zur Dopplersonografie ermöglicht die transkranielle Duplexsonografie durch die Darstellung des Hirngewebes, das die intrakraniellen Arterien umgibt, den Nachweis der Penetration des Ultraschalls durch den Schädelknochen und die Lokalisation der intrakraniellen Arterien jeweils unabhängig vom Vorliegen eines Blutflusses in diesen Arterien“ [1]. „Als Signalverstärker eingesetzte Ultraschallkontrastmittel erhöhen die Sensitivität der Duplexsonografie, um die für einen zerebralen Zirkulationsstillstand charakteristischen Strömungssignale an den intrakraniellen Arterien nachzuweisen“ [1, 39, 40]. In Deutschland ist für die kontrastverstärkte Ultraschallbildgebung (CEUS) der Hirnbasisarterien zurzeit nur das Ultraschallkontrastmittel SonoVue ${ }^{\circledR}$ (Bracco Imaging Deutschland) zugelassen, und zwar in den Fällen, in denen die Ultraschalluntersuchung ohne Kontrastmittel nicht aussagekräftig ist; für Details zur CEUS sei auf frühere Arbeiten verwiesen [39-41]. Die darzustellenden Gefäßabschnitte der A. carotis interna und der A. vertebralis sind in einigen Details unterschiedlich für die Dopplersonografie und die Duplexsonografie in der RL4-BÄK festgelegt worden [1], folgen aber dem gleichen Grundprinzip, dass jedes Gefäß nur noch an einem Abschnitt dargestellt werden muss ( $\odot$ Tab.3, $\odot$ Abb. 2). Dies wird in der RL4-BÄK ausführlich wie folgt begründet [1]: „Die Untersuchung der Aa. carotides internae und der Aa. vertebrales in den extra- und intrakraniellen Abschnitten wird nicht gefordert, da prinzipiell keine Notwendigkeit besteht, eine Arterie an mehreren Stellen abzuleiten. Voraussetzung dafür ist allerdings, dass jede einzelne Ableitung technisch suffizient möglich ist und deren Untersuchungsergebnis für sich allein eine eindeutige Schlussfolgerung erlaubt. Dies ist bei

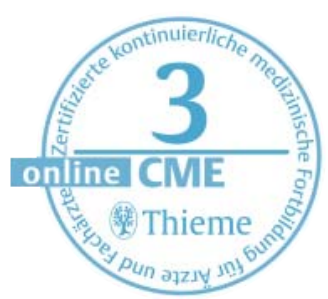


Table 3 Examination protocol for the determination of cerebral circulatory arrest according to the guidelines in Germany: comparison of the previous and the current guidelines of the German Medical Association (GMA).

\begin{tabular}{llll} 
& GMA guidelines 1998 & GMA guidelines 2015 \\
& Doppler sonography & Doppler sonography & Duplex sonography \\
\hline extracranial & & & \\
- bilateral ICA & + & $(+)^{1}$ & $(+)^{1}$ \\
\hline - bilateral VA & + & +2 & $(+)^{1}$ \\
\hline intracranial & & & +2 \\
\hline - bilateral ICA & + & +2 & + \\
\hline - bilateral MCA & + & + & +2 \\
\hline - bilateral VA & + & & + \\
\hline - BA & & & $+^{3}$ \\
\hline - "other detectable" & $+^{3}$ & $+^{3}$ &
\end{tabular}

ICA: internal carotid artery; VA: vertebral artery; MCA: middle cerebral artery; BA: basilar artery.

${ }^{1}$ extracranial examination only if the intracranial vessel segments are not detectable.

2 examination of the ICA and VA at both extra- and intracranial locations is not required since there is no necessity to document the same artery at various locations [1].

3 optional examination of other basal brain arteries if detectable.

[1] but follow the same basic principle that only one segment of every vessel has to be imaged ( $\bullet$ Table 3, 0 Fig. 2). This is justified in the guidelines as follows [1]: "The internal carotid arteries and the vertebral arteries do not need to be examined in extracranial and intracranial segments since it is not necessary to document the same artery at multiple locations. However, technically sufficient measurement must be possible and the examination results must be conclusive. This is the case for intracranial as well as extracranial documentation of the internal carotid artery. Consequently, when documentation at one location is not technically feasible, diagnosis can be made by documenting at a different location. Extracranial documentation despite intracranial signals of cerebral circulatory arrest in the internal carotid arteries could even unnecessarily prevent diagnosis with Doppler/duplex sonography in the case of technical obstacles (e. g. central vein catheter). In the case of duplex sonographic detection of signals in the basilar artery and both V4 segments from which the posterior inferior cerebellar arteries (PICA) originate that are characteristic for cerebral circulatory arrest, it is not necessary to document these signals also in the extracranial vertebral arteries for the reasons mentioned above. Requiring additional extracranial documentation of these signals could result in flow signals that would unnecessarily prevent the diagnosis of cerebral circulatory arrest with duplex sonography due to the collateral connections of the vertebral arteries to the relevant external carotid artery" [1].

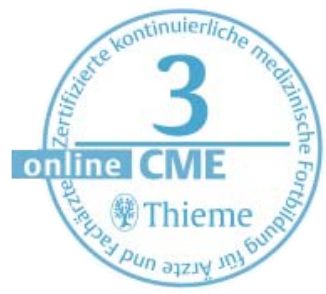

\section{Findings of cerebral circulatory arrest}

Early systolic spikes with a maximum systolic velocity of less than $50 \mathrm{~cm} / \mathrm{s}$ and a duration of less than $200 \mathrm{~ms}$ and biphasic flow signals (oscil- lating flow signals, "pendular flow") are Doppler sonographic signs of cerebral circulatory arrest ( $\bullet$ Fig.3-5). "Biphasic flow signals can then only be used to determine cerebral circulatory arrest when the integral (area) of the anterograde and retrograde segments of the Doppler frequency spectrum within one cardiac cycle are equally sized. It is not necessary to perform a measurement with the ultrasound unit. In practice this is estimated by the examiner" [1]. The biphasic flow signals after cerebral circulatory arrest can still have relatively high amplitudes in the orthograde systolic flow component to over $100 \mathrm{~cm} / \mathrm{s}$ but are characterized by a narrow monophasic configuration of the orthograde systolic flow component ("systolic spikes") [42, 43]. Flow signals with a wide biphasic configuration of the orthograde systolic flow component ( $\bullet$ Fig. 6 ) should not be evaluated with respect to cerebral circulatory arrest. Spontaneous or post-traumatic arteriovenous shunt flows (AV fistula) that also do not allow sonographic diagnosis of cerebral circulatory arrest are occasionally also detected ( $\bullet$ Fig. $\mathbf{6}$ ).

The guidelines newly specify the following criteria for determining cerebral circulatory arrest via Doppler or duplex sonography:

"To detect cerebral circulatory arrest, the following must be performed twice with a waiting period of at least 30 minutes:

\section{$\checkmark$ via Doppler sonography}

intracranial examination of the middle cerebral arteries, internal carotid arteries, and any additional detectable basal brain arteries and extracranial examination of the vertebral arteries and, if the corresponding intracranial vessel segments cannot be visualized, of the internal carotid arteries

or

\section{via duplex sonography}

intracranial examination of the M1 segments of the middle cerebral arteries, the internal carotid arteries, the V4 segments of the vertebral arteries, the basilar artery and any additional detectable basal brain arteries via duplex sonography

and the following findings must be able to be verified:

biphasic flow signals (oscillating flow signals) with equally sized integral of the anterograde and retrograde component

or

- early systolic spikes that are smaller than $50 \mathrm{~cm} / \mathrm{s}$ and last less than $200 \mathrm{~ms}$ with no additional flow signal in the remaining cardiac cycle being able to be detected.

A lack of flow signals on transcranial sonography of the basal brain arteries can only be evaluated as a conclusive sign of cerebral circulatory arrest if the same examiner documented definite intracranial flow signals in an earlier examination using the same system settings or when the signs of cerebral circulatory arrest can be detected in the extracra- 
Ableitung der Aa. carotides internae intrakraniell und extrakraniell jeweils der Fall. Konsequenterweise kann, wenn die Ableitung an einer Stelle technisch nicht möglich ist, die Aussage durch Ableitung an einer anderen Stelle getroffen werden. Praktisch könnte die Forderung, trotz intrakranieller Signale des zerebralen Kreislaufstillstands in den Aa. carotides internae, diese auch extrakraniell abzuleiten, bei technischen Hindernissen (z. B. zentraler Venenkatheter) sogar unnötigerweise die Diagnose doppler-/duplexsonografisch nicht erlauben. Bei duplexsonografischem Nachweis der für einen zerebralen Kreislaufstillstand charakteristischen Signale in der A. basilaris und beiden V4-Segmenten, von denen die Aa. cerebelli inferiores posteriores (sog. PICA) abgehen, besteht aus oben genannten Gründen ebenfalls keine Notwendigkeit, diese Signale auch in den extrakraniellen Aa. vertebrales abzuleiten. Die Forderung, diese Signale auch extrakraniell abzuleiten, könnte, aufgrund der Kollateralverbindungen der Aa. vertebrales zur jeweiligen A. carotis externa, extrakraniell unter Umständen zu Strömungssignalen führen, die unnötigerweise die Diagnose des zerebralen Kreislaufstillstands duplexsonografisch nicht erlauben würden“ [1].

\section{Befunde des zerebralen Zirkulationsstill- stands \\ $\nabla$}

Frühsystolische Spitzen, die eine systolische Maximalgeschwindigkeit von kleiner als $50 \mathrm{~cm} / \mathrm{s}$ und eine Dauer von unter $200 \mathrm{~ms}$ aufweisen, und biphasische Strömungssignale (oszillierende Strömungssignale, „Pendelfluss") sind dopplersonografische Zeichen eines zerebralen Zirkulationsstillstands ( $\bullet$ Abb. 3-5). "Biphasische Strömungssignale sind nur dann verwertbar für einen zerebralen Zirkulationsstillstand, wenn das Integral (Fläche) der anterograden und retrograden Anteile des Dopplerfrequenzzeitspektrums innerhalb eines Herzzyklus gleich ausgeprägt ist; es wird nicht gefordert, dass hier eine Messung durch das Ultraschallgerät erfolgen soll, in der Praxis wird das durch den Untersucher abgeschätzt" [1]. Die biphasischen Strömungssignale nach zerebralem Zirkulationsstillstand können dabei durchaus noch relativ hohe Amplituden der orthograden systolischen Flusskomponente bis über $100 \mathrm{~cm} / \mathrm{s}$ haben, sind aber charakterisiert durch eine schmale monophasische Konfiguration der orthograden systolischen Flusskomponente („systolische Spitzen“) [42, 43]. Strömungssignale mit breiter oder angedeuteter biphasischer Konfiguration der orthograden systolischen Flusskomponente ( $\bullet$ Abb. 6) sollten nicht im Sinne eines zerebralen Zirkulationsstillstands gewertet werden. Gelegentlich werden auch spontane oder posttraumatische arteriovenöse Shuntflüsse (AV-Fistel) detektiert, die die sonografische Diagnosestellung eines zerebralen Zirkulationsstillstands ebenfalls nicht erlauben ( $\odot$ Abb. $\mathbf{6})$.
Tab.3 Untersuchungsprogramm zum Nachweis des zerebralen Zirkulationsstillstands gemäß den Richtlinien in Deutschland: Vergleich der früheren und der aktuellen BÄK-Richtlinie (RL4BÄK).

\begin{tabular}{|c|c|c|c|}
\hline & BÄK-Richtlinie 1998 & BÄK-Richtlinie 2015 & \\
\hline & Dopplersonografie & Dopplersonografie & Duplexsonografie \\
\hline \multicolumn{4}{|l|}{ Extrakraniell } \\
\hline - beidseits $\mathrm{ACl}$ & + & $(+)^{1}$ & $(+)^{1}$ \\
\hline - beidseits AV & + & +2 & $(+)^{1}$ \\
\hline \multicolumn{4}{|l|}{ Intrakraniell } \\
\hline - beidseits $\mathrm{ACl}$ & + & +2 & +2 \\
\hline - beidseits ACM & + & + & + \\
\hline - beidseits AV & + & & +2 \\
\hline$-A B$ & & & + \\
\hline - „jede weitere“ & $t^{3}$ & +3 & $++^{3}$ \\
\hline
\end{tabular}

ACI: A. carotis interna; AV: A. vertebralis; ACM: A. cerebri media; AB: A. basilaris.

${ }^{1}$ Untersuchung nur, wenn die intrakraniellen Gefäßsegmente nicht darstellbar sind.

${ }^{2}$ Die Untersuchung der ACl und der AV in den extra- und intrakraniellen Abschnitten wird nicht gefordert, da keine Notwendigkeit besteht, eine Arterie an mehreren Stellen abzuleiten [1].

${ }^{3}$ Optionale Untersuchung weiterer Hirnbasisarterien, wenn detektierbar.

Die RL4-BÄK gibt die folgenden Kriterien für die Feststellung des zerebralen Zirkulationsstillstands mittels Doppler- oder Duplexsonografie neu vor:

„Zum Nachweis des zerebralen Zirkulationsstillstands müssen im Abstand von mindestens 30 Minuten

\section{mittels Dopplersonografie}

intrakraniell die Aa. cerebri mediae, Aa. carotides internae und eventuell detektierbare weitere Hirnbasisarterien, extrakraniell die Aa. vertebrales und, wenn die korrespondierenden intrakraniellen Gefäßsegmente nicht darstellbar sind, die Aa. carotides internae,

oder

\section{mittels Duplexsonografie}

intrakraniell die M1-Segmente der Aa. cerebri mediae, die Aa. carotides internae, die V4-Segmente der Aa. vertebrales und die A. basilaris sowie eventuell detektierbare weitere Hirnbasisarterien

untersucht werden und dabei folgende Befunde nachweisbar sein:

- biphasische Strömungssignale (oszillierende Strömungssignale) mit gleich ausgeprägtem Integral der antero- und retrograden Komponente oder

- frühsystolische Spitzen, die kleiner als $50 \mathrm{~cm} / \mathrm{s}$ sind und unter $200 \mathrm{~ms}$ anhalten, wobei kein weiteres Strömungssignal im verbleibenden Herzzyklus detektierbar sein darf.

Ein Fehlen der Strömungssignale bei transkranieller Beschallung der Hirnbasisarterien kann nur dann als sicheres Zeichen eines zerebralen Zirkulationsstillstands gewertet werden, wenn derselbe Untersucher mit gleicher Geräteeinstellung während einer früheren Untersuchung eindeutig ableitbare intrakranielle Strömungssignale dokumentiert hat, oder wenn an den extrakraniellen hirnversorgenden Arterien (Aa. carotides internae, Aa. vertebrales) die Zeichen des zerebralen Zirkulationsstillstands nachweisbar sind“" [1]. Pri-

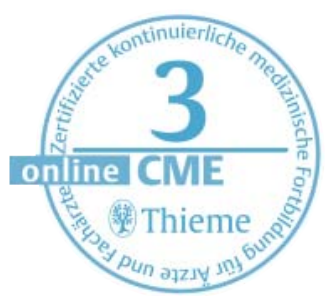




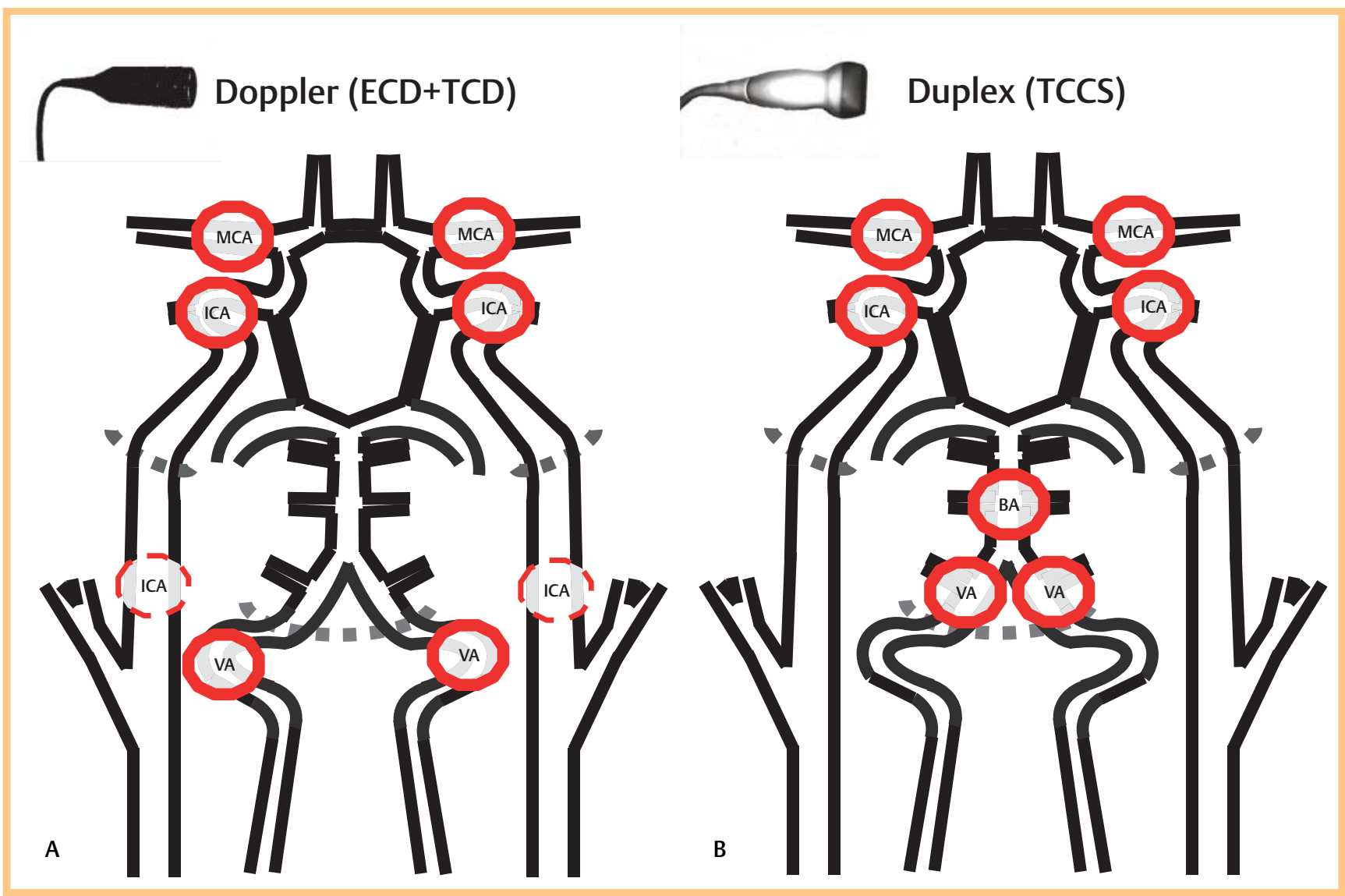

Fig. 2 Schemes showing the arteries that must be documented with Doppler sonography $\mathbf{A}$ or duplex sonography $\mathbf{B}$ for the determination of cerebral circulatory arrest according to the guidelines valid in Germany.

Abb.2 Darzustellende Gefäße bei Verwendung der Dopplersonografie A bzw. der Duplexsonografie B zur Diagnostik des zerebralen Zirkulationsstillstands gemäß den in Deutschland geltenden Richtlinien.

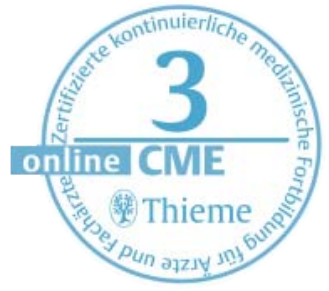

nial brain-supplying arteries (internal carotid arteries, vertebral arteries)" [1]. A primary lack of flow signals may not be evaluated as proof of irreversibility since intracranial flow signals can be lacking despite continued brain perfusion in the case of insufficient sound transmission through bone, intracranial air, or massive vascular displacement [3]. Doppler and duplex sonography findings can be affected by a number of possible errors ( $\triangle$ Table 4) that must be taken into consideration or ruled out $[44,45]$. The second examination performed after a waiting period of 30 minutes is intended to ensure that the circulatory arrest is not simply temporary and reversible. The time of the start of each sonographic examination is significant, i.e., the second examination can be started 30 minutes after the start of the first examination at the earliest (or later) [46]. This time period $\geq 30$ minutes must be documented accordingly in the examination report and in the records.

On its own (i. e., when the clinical determination of irreversible cessation of brain function is used as the diagnostic gold standard for comparison), TCD has a sensitivity of $90 \%$ (95\% confidence interval: $87-92 \%$ ) and a specificity of $98 \%$ (96$99 \%$ ) in the diagnosis of irreversible cessation of brain function according to a current meta-analysis [47]. If Doppler or duplex sonography is performed according to the specifications described here and after the standardized determination of the clinical symptoms of cessation of brain function according to the guidelines of the German Medical Association and cerebral circulatory arrest is confirmed in two examinations performed at an interval of 30 minutes, false-positive results are not to be expected according to the current state of medical science (i.e., $100 \%$ specificity of Doppler/duplex sonography) [26, 45, 46].

\section{System requirements \\ $\nabla$}

In general, all ultrasound systems that are commercially available in the European Union and are configured for examination of the extracranial and intracranial brain-supplying arteries can be used. Suitable probes are required (Doppler sonography, extracranial: 4-MHz probe, transcranial: $2-\mathrm{MHz}$ probe; duplex sonography, extracranial: 5-10$\mathrm{MHz}$ probe, transcranial: $1-2.5-\mathrm{MHz}$ probe). To ensure the detection of low-volume or slow flows 


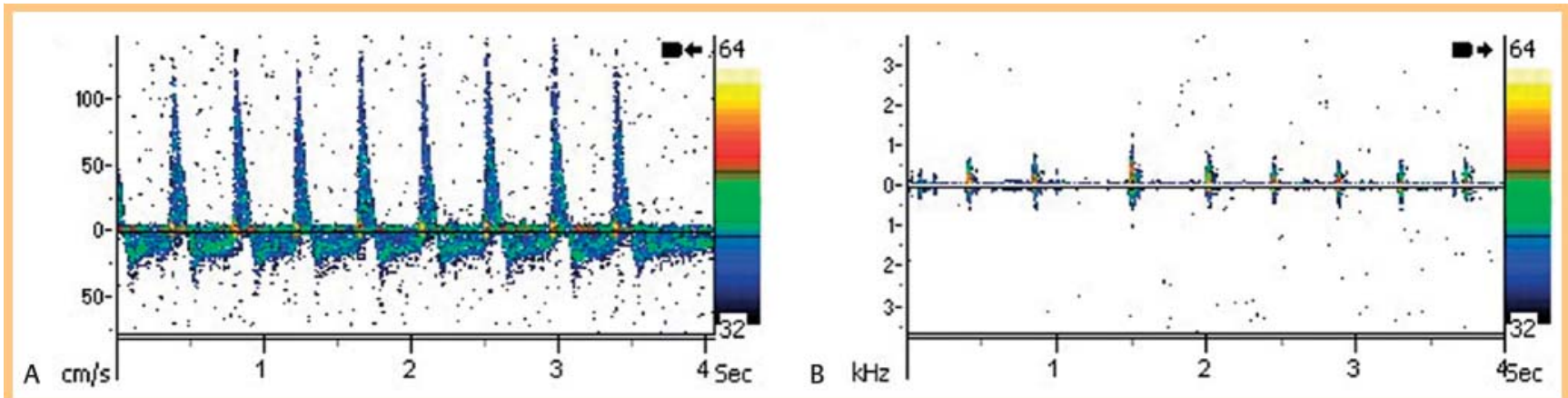

Fig. 3 Doppler sonography findings in cerebral circulatory arrest. The Doppler flow curve in panel A shows a biphasic (oscillating) flow signal in the middle cerebral artery. The Doppler flow curve in panel B shows "systolic spikes" in the middle cerebral artery.

Abb. 3 Dopplersonografische Befunde beim zerebralen Zirkulationsstillstand. Die in Bild A dargestellte Doppler-Kurve zeigt ein biphasisches (oszillierendes) Strömungssignal in der A. cerebri media. Die in Bild B dargestellte Doppler-Kurve zeigt „systolische Spitzen“ in der A. cerebri media.
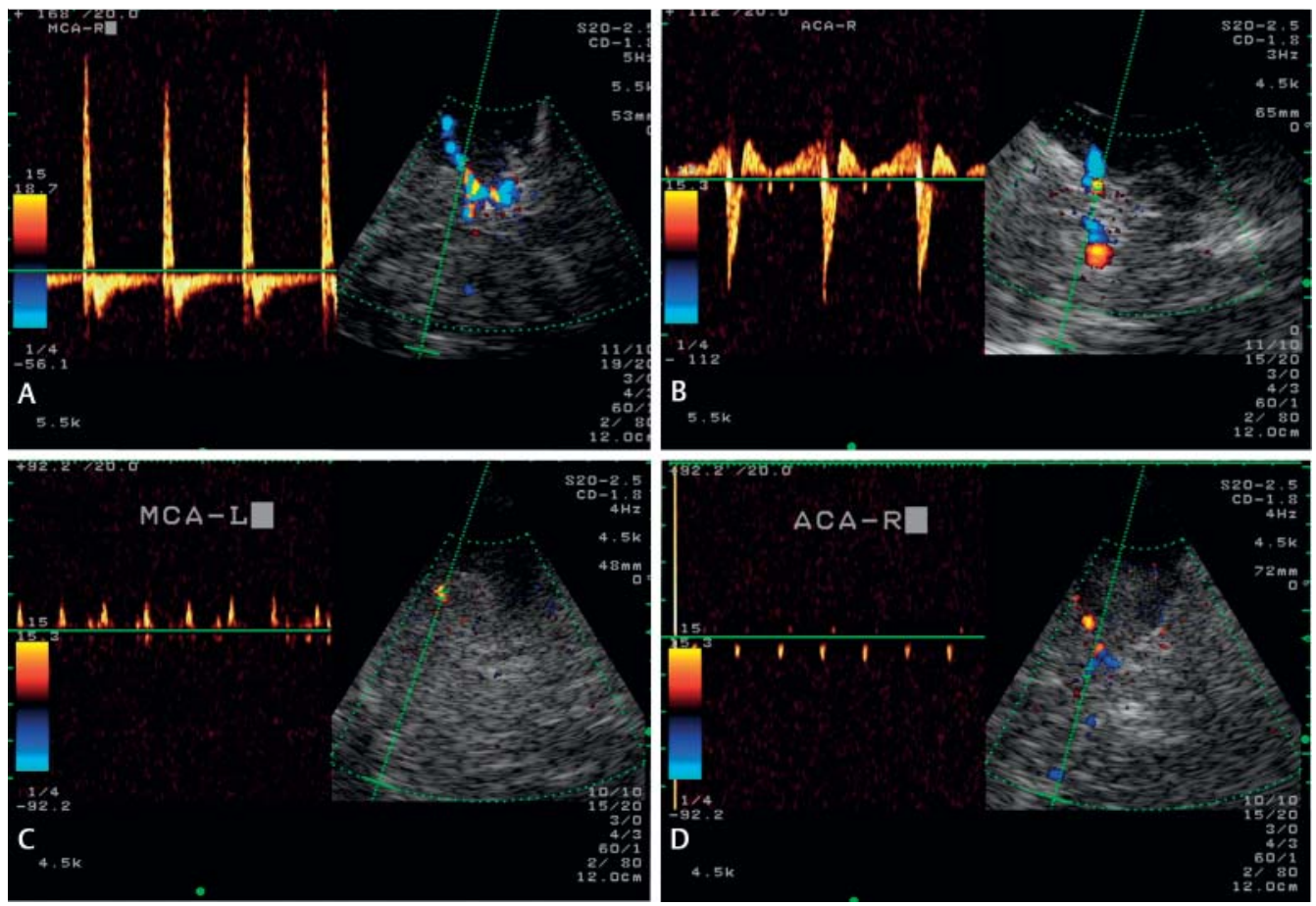

mär fehlende Strömungssignale dürfen nicht als Irreversibilitätsnachweis gewertet werden, da intrakranielle Strömungssignale bei unzureichender Schalltransmission durch den Knochen, intrakranieller Luftansammlung oder massiver Gefäßverlagerung trotz noch erhaltener Hirndurchblutung fehlen können [3]. Die Befunderhebung mittels Doppler- und Duplexsonografie kann durch eine Reihe von Fehlermöglichkeiten beeinträchtigt werden ( $\bullet$ Tab.4), welche unbedingt beachtet oder ausgeschlossen werden müssen $[44,45]$. Die zweite Untersuchung in zeitlichem Abstand von 30 Minuten soll sicherstellen, dass es sich nicht nur um einen kurzzeitigen, reversiblen Zirkulationsstillstand handelt. Dabei ist der Zeitpunkt des Beginns der jeweiligen sonografischen Untersuchung maßgeblich; das heißt, die zweite Untersuchung kann frühestens $30 \mathrm{Mi}$ - nuten nach Beginn der Erstuntersuchung (oder aber auch später) begonnen werden [46]. Im Untersuchungsbefund wie auch in den Protokollbögen muss dementsprechend diese Zeitspanne $\geq 30$ Minuten dokumentiert sein.

Für sich allein (d.h., wenn die klinische Feststellung des irreversiblen Hirnfunktionsausfalls als diagnostischer „Goldstandard“ zum Vergleich dient) hat die TCD gemäß einer aktuellen Metaanalyse eine Sensitivität von 90\% (95\%iges Konfidenzintervall: 87 - 92\%) und eine Spezifität von 98\% (9699\%) in der Diagnose des irreversiblen Hirnfunktionsausfalls [47]. Wird die Doppler- oder Duplexsonografie gemäß den hier ausführlich dargestellten Vorgaben und zeitlich nach der standardisierten Feststellung der klinischen Symptome des Hirnfunktionsausfalls gemäß RL4-BÄK durchgeführt und der zerebrale Zirkulationsstillstand bei zwei-
Fig. 4 Findings with transcranial color-coded duplex sonography (TCCS) in cerebral circulatory arrest. Panels $\mathbf{A}$ and $\mathbf{B}$ show characteristic biphasic flow signals in the middle cerebral artery and the anterior cerebral artery. Panels C and D show "systolic spikes" in the middle cerebral artery and the anterior cerebral artery.

Abb. 4 Befunde der transkraniellen Farbduplexsonografie (TCCS) beim zerebralen Zirkulationsstillstand. Die Bilder $\mathbf{A}$ und B zeigen typische biphasische Strömungssignale in der A. cerebri media und $A$. cerebri anterior. Die Bilder $\mathbf{C}$ und $\mathbf{D}$ zeigen „systolische Spitzen“ in der A. cerebri media und $\mathrm{A}$. cerebri anterior.

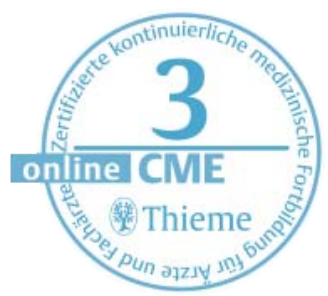


Fig. 5 Findings with extracranial color-coded duplex sonography (ECCS)in cerebral circulatory arrest. Panels $\mathbf{A}$ and $\mathbf{B}$ show characteristic biphasic flow signals in the internal carotid artery and the vertebral artery. Panel $\mathbf{C}$ shows the preserved flow in the external carotid artery. Panel D shows a transorbital sonogram of dilated optic nerve sheath (double arrow) due to increased intracranial pressure, which however does not allow for a reliable diagnosis of irreversible loss of brain function (brain death) [23].

Abb.5 Befunde der extrakraniellen Farbduplexsonografie (ECCS) beim zerebralen Zirkulationsstillstand. Die Bilder $\mathbf{A}$ und $\mathbf{B}$ zeigen typische biphasische Strömungssignale in der A. carotis interna und der $\mathrm{A}$. vertebralis. Das Bild C zeigt den erhaltenen Fluss in der A. carotis externa. Das Bild $\mathbf{D}$ zeigt die transorbitale Sonografie der erweiterten Nervus-opticus-Scheide (Doppelpfeil) bei erhöhtem Hirndruck, die allerdings keine zuverlässige Diagnostik in der Feststellung des irreversiblen Hirnfunktionsausfalls erlaubt [23].
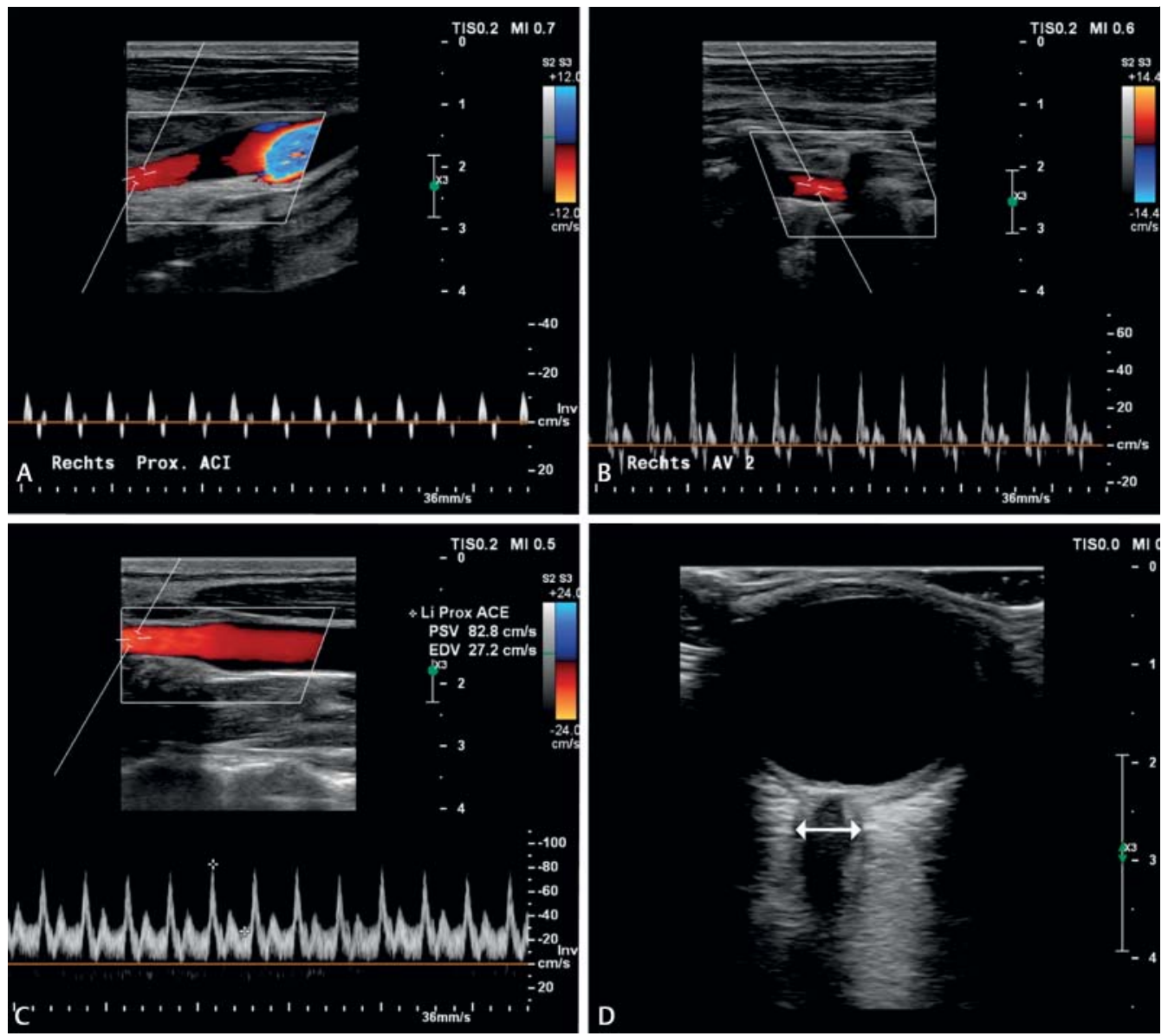

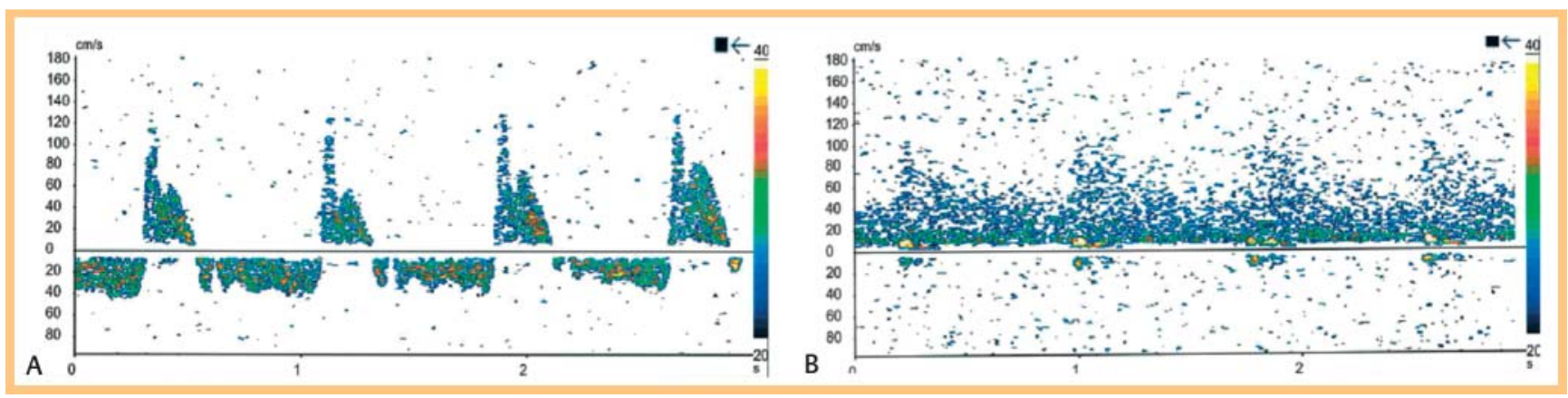

Fig. 6 Doppler sonography findings causing uncertainty in the diagnosis of cerebral circulatory arrest. The Doppler flow curve in panel A shows a large-volume pendular flow with a wide, biphasic configuration of the orthograde systolic flow component. In this situation cerebral circulatory arrest might be present. However, it cannot be diagnosed with this Doppler finding since minimal brain perfusion cannot be excluded. The Doppler flow curve in panel $\mathbf{B}$ shows an arteriovenous shunt flow, superimposed by systolic spikes (proximal middle cerebral artery). Also this finding does not allow for the sonographic diagnosis of cerebral circulatory arrest. In both cases A, B brain perfusion scintigraphy ultimately demonstrated cerebral circulatory arrest.

Abb. 6 Dopplersonografische Befunde, bei denen Unsicherheit in der Diagnose des zerebralen Zirkulationsstillstands besteht. Die in Bild A dargestellte DopplerKurve zeigt einen großvolumigen Pendelfluss mit breiter, biphasischer Konfiguration der orthograden systolischen Flusskomponente; hier kann zwar ein zerebraler Zirkulationsstillstand vorliegen, dieser kann jedoch mit diesem Dopplerbefund nicht festgestellt werden, da eine Restperfusion von Hirnarealen nicht sicher ausgeschlossen ist. Die in Bild B dargestellte Doppler-Kurve zeigt einen arterio-venösen Shuntfluss, überlagert durch systolische Spitzen (proximale A. cerebri media). Auch dieser Befund erlaubt die sonografische Diagnose eines zerebralen Zirkulationsstillstands nicht. In beiden Fällen A, B konnte der zerebrale Zirkulationsstillstand schließlich mittels Perfusions-Szintigrafie bewiesen werden.

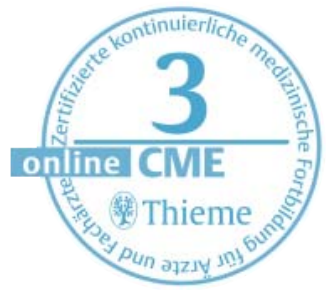

via Doppler or duplex sonography, suitable system settings must be selected ( $\bullet$ Table 5 ).

\section{Requirements regarding examiners \\ $\nabla$}

"Examinations must be performed by a physician with sufficient experience with this specific diagnostic application of sonography" [1]. This can also be a qualified physician who performs this 
maliger Untersuchung im Abstand von 30 Minuten bestätigt, sind nach aktuellem Stand der wissenschaftlichen Erkenntnisse keine falsch-positiven Ergebnisse zu erwarten (somit eine 100\%ige Spezifität der Doppler-/Duplexsonografie) [26, 45, 46].

\section{Apparative Anforderungen \\ $\nabla$}

Grundsätzlich können alle kommerziell in der Europäischen Union verfügbaren Ultraschallsysteme, die für die Untersuchung der extra- und intrakraniellen hirnversorgenden Arterien konfiguriert sind, verwendet werden. Voraussetzung sind geeignete Sonden (Dopplersonografie extrakraniell: 4-MHz-Sonde, transkraniell: 2-MHz-Sonde; Duplexsonografie extrakraniell: 5-10-MHz-Sonde, transkraniell: 1 - 2,5-MHz-Sonde). Um die Detektion niedrigvolumiger oder langsamer Flüsse mittels der Doppler- oder Duplexsonografie sicherzustellen, sind geeignete Geräteeinstellungen zu wählen (৫ Tab.5).

\section{Anforderungen an den Untersucher $\nabla$}

"Die Untersuchung muss durch einen in dieser Methode speziell erfahrenen Arzt durchgeführt werden" [1]. Dies kann auch ein qualifizierter Arzt sein, der diese Leistung konsiliarisch erbringt. In den Fachgremien der Deutschen Gesellschaft für Ultraschall in der Medizin (DEGUM) und der Deutschen Gesellschaft für Klinische Neurophysiologie und Funktionelle Bildgebung (DGKN) hat es eine intensive Diskussion darüber gegeben, ob ein Zertifikat des Untersuchers als Voraussetzung für die Durchführung der sonografischen Diagnostik im Rahmen der Hirntoddiagnostik zu fordern ist. Davon ist schließlich abgesehen worden, um langjährig erfahrenen Untersuchern in dieser Indikation, die evtl. kein Zertifikat haben, weiterhin die Möglichkeit der Durchführung zu geben. Dennoch sehen die Autoren es als wünschenswert und sinnvoll an, dass die in dieser Indikation (in Deutschland) tätigen Ärzte ein Zertifikat der DEGUM oder DGKN für die Doppler-/Duplexsonografie der hirnversorgenden Arterien erwerben, um damit ihre Kompetenz formal zu dokumentieren. Alternative für das DEGUM- bzw. DGKN-Zertifikat für die Doppler-/Duplexsonografie der hirnversorgenden Gefäße kann ein international gültiges Zertifikat sein wie die „International Certification in Neurosonology“ der Neurosonology Research Group of the World Federation of Neurology (NSRG-WFN), die in Europa bei der European Society of Neurosonology and Cerebral Hemodynamics (ESNCH) nach Ablegen einer Prüfung erworben werden kann (siehe auch: http://esnch.org/en/Education_1181. html).

\section{Anforderungen an den Befundbericht}

$\nabla$

Gemäß den aktualisierten Empfehlungen der DGKN soll der Befundbericht neben den üblichen Informationen (Fragestellung, Befundbeschreibung, Beurteilung) die folgenden Angaben enthalten [3]: Untersuchungszeit (Datum, Uhrzeit), Blutdruck (arterieller Mitteldruck oder systolischer und diastolischer Blutdruck), Benennung der dargestellten Gefäße mit der Art der jeweils detektierten Strömungssignale (frühsystolische Spitzen, biphasische Strömung mit gleich ausgeprägtem Integral der antero- und retrograden Komponente, erhaltene Perfusion, kein Strömungssignal nachweisbar), im Falle fehlender transkranieller Strömungssignale ggf. Vergleich mit der von demselben Untersucher durchgeführten Voruntersuchung beschreiben, Name des untersuchenden/befundenden Arztes und Form der Archivierung der abgeleiteten Strömungssignale angeben (Papierausdruck oder digital). Wenn im Anschluss an die Feststellung des irreversiblen Hirnfunktionsausfalls (ggf. mit Durchführung der Doppler- bzw. Duplexsonografie) eine Organ- oder Gewebespende durchgeführt wird, erfolgt die Archivierung des Befundberichts (nicht unbedingt der einzelnen Original-Bildausdrucke) für 30 (dreißig!) Jahre [1].

\section{Vorgehen bei unvollständiger Untersuch-}

barkeit oder unsicheren Befunden

Wenn die doppler-/duplexsonografische Untersuchung nicht vollständig gemäß den Vorgaben der RL4-BÄK abgeschlossen werden kann, ist der Einsatz einer alternativen Methode zum Nachweis des zerebralen Zirkulationsstillstands (KMgestützte CTA, Perfusionsszintigrafie) möglich [1]. Dies gilt ebenso in Fällen, in denen extra-intrakranielle Shuntflüsse in der Doppler-/Duplexsonografie nachgewiesen werden. Diese Konstellation kann nach sekundären Hirnschädigungen beobachtet werden, wenn kein schweres Hirnödem, kein maximal erhöhter Hirndruck und damit kein zerebraler Zirkulationsstillstand entsteht. Des Weiteren besteht die - in der Praxis seltene - Möglichkeit, dass mit dem zunehmenden Entstehen von Hirnnekrosen die eingetretenen doppler-/duplexsonografischen Zeichen des Zirkulationsstillstands (systolische Spitzen, biphasische Strömungssignale) partiell wieder verschwinden und dass wieder schwache orthograde Flüsse auftreten [48]. Mittels TCCS kann die Diagnose des Zirkulationsstillstands gemäß RL4-BÄK auch dann nicht gestellt werden, wenn der Fluss in der intrakraniellen A. carotis interna in Richtung der A. ophthalmica erhalten ist, selbst wenn typische Flusssignale (systolische Spitzen, biphasische Strömungssignale) beidseits in der A. cerebri media, A. cerebri anterior, A. cerebri posterior, A. basilaris und A. vertebralis (V4-Segment) nachgewiesen werden. Diese falsch-negative sonografische Befundkonstellation, die gelegentlich bei irreversiblem Hirnfunktionsausfall vorliegt [49], wurde

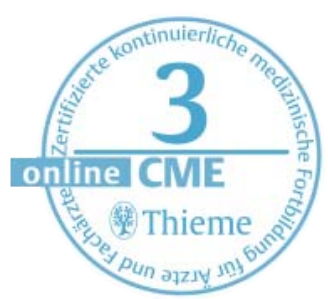


Table 4 Pitfalls (modified from Günther et al. [45]).
1. primarily undetectable flow signals must not be interpreted on their own as proof of cerebral circulatory arrest.

2. false-negative findings may be obtained in the case of larger skull bone defects, or in infants with a fontanel that is still open.

3. pronounced tachycardia (e. g. tachyarrhythmia, sinus tachycardia $>120 / \mathrm{min}$ ) may simulate remaining flow due to the overlap of pulse waves.

4. pronounced bradycardia may extend the duration of systolic spikes to more than $200 \mathrm{~ms}$ which precludes their use for diagnosing cerebral circulatory arrest according to the guidelines of the German Medical Association.

5. incidentally detected weakly pulsatile intracranial venous flow signals may result in false-negative findings (supposed arterial cerebral blood flow).

6. artifacts or flow changes due to intra-aortic balloon pump (IABP), extracorporeal membrane oxygenation (ECMO), or mechanical ventilation may make it difficult to interpret sonographic findings.
Table 5 Method for the determination of cerebral circulatory arrest.

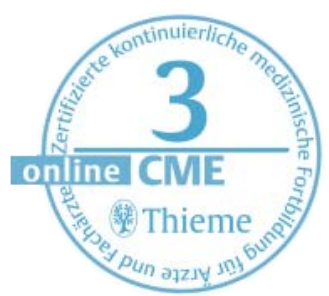

\section{transcranial Doppler sonography (TCD)}

1. measure the arterial blood pressure: mean arterial pressure in adults $>60 \mathrm{~mm} \mathrm{Hg}$ (for children, see $\rightarrow$ Tab. 2).

2. use the 2-MHz probe.

3. start with high transmitting power and receiver gain settings since otherwise flow signals of low intensity may not be detected.

4. turn off the envelope of the wave spectrum since it is more confusing than helpful.

5. set the wall filter (high-pass filter) to a low value $\leq 50 \mathrm{~Hz}$ since otherwise systolic spikes may be filtered off.

6. choose a large sample volume $(15 \mathrm{~mm})$.

7. start the examination at greater depths since the distal segments of the middle cerebral artery can be compressed or shifted.

transcranial color-coded duplex sonography (TCCS) ${ }^{1}$

1. measure the arterial blood pressure: mean arterial pressure in adults $>60 \mathrm{~mm} \mathrm{Hg}$ (for children, see $\bigcirc$ Tab. 2).

2. use the 1- to $2.5-\mathrm{MHz}$ probe.

3. do not choose a color window that is too large.

4. optimize (reduce) the pulse repetition frequency (PRF) to detect low flow signals.

5 . increase the color gain (receiver gain in color mode).

6. choose the correct imaging planes using anatomical landmarks in the B-mode image for the identification of the relevant arteries: a) upper pontine plane (meeting point of the wing of sphenoid bone and the petrosal bone) for ICA siphon and ophthalmic artery; b) lower pontine plane (petrosal bone) for petrosal ICA; c) midbrain plane for circulus arteriosus (Willisii).

7. in the case of missing intracranial flow signals yet visible structures on the B-mode image consider the use of an ultrasound contrast agent.

${ }^{1}$ Duplex mode imaging allows the exact topographic assignment of Doppler signals being used for diagnosing cerebral circulatory arrest.

task by way of consultation. The committees of the German Society of Ultrasound in Medicine (DEGUM) and the German Society for Clinical Neurophysiology and Functional Imaging (DGKN) discussed whether examiners are to be required have certification to be able to use sonography to diagnose brain death. This requirement was ultimately not enforced in order to allow examiners with many years of experience in this indication who may not have certification to continue to perform examinations. However, the authors of this article think it would be beneficial for physicians performing such examinations (in Germany) to obtain certification from the DEGUM or DGKN for Doppler/duplex sonography of the brain-supplying arteries in order to officially document their competence. An alternative to the DEGUM or DGKN certification for Doppler/ duplex sonography of brain-supplying vessels is internationally valid certification such as "International Certification in Neurosonology" of the Neurosonology Research Group of the World Federation of Neurology (NSRG-WFN) that can be acquired in Europe from the European Society of Neurosonology and Cerebral Hemodynamics
(ESNCH) after passing an exam (refer to: http:// esnch.org/en/Education_1181.html).

\section{Results report requirements}

According to the updated recommendations of the DGKN, the results report should contain the usual information (issue, description of findings, assessment) as well as the following information [3]: Examination time (date, time), blood pressure (mean arterial pressure or systolic and diastolic blood pressure), naming of the visualized vessels with the type of detected flow signals (early systolic spikes, biphasic flow with equally sized integral of the anterograde and retrograde component, preserved perfusion, no detectable flow signal). In the case of a lack of transcranial flow signals, provide comparison with the earlier examination performed by the same examiner if applicable. Specify the name of the examining/interpreting physician, and specify the type of archiving of the documented flow signals (paper printout or digital). If organ or tissue donation is to be performed following determination of irreversible cessation of brain function (with Doppler 
1. Primär fehlende Strömungssignale dürfen für sich allein nicht als Nachweis des zerebralen Zirkulationsstillstands gewertet werden.

2. Falsch-negative Befunde können bei größeren Knochendefekten oder Kleinkindern mit noch nicht verschlossener Fontanelle erhoben werden.

3. Starke Tachykardie (Tachyarrhythmie, Sinustachykardie >120/min) kann durch Überlagerung der Pulswellen eine noch vorhandene Strömung vortäuschen.

4. Starke Bradykardie kann die Dauer systolischer Spitzen auf über 200 ms verlängern, was die Wertung im Sinne eines zerebralen Zirkulationsstillstands gemäß RL4-BÄK ausschließt.

5. Gelegentlich intrakraniell nachweisbare, schwach pulsatile venöse Flusssignale können zu falsch-negativen Befunden führen (vermeintlicher arterieller zerebraler Blutfluss).

6. Artefakte oder Flussveränderungen aufgrund von intraaortaler Ballonpumpe (IABP), arteriovenöser extrakorporaler Membranoxygenierung (ECMO) oder Beatmung können zu schwer interpretierbaren Befunden führen.

\section{Transkranielle Dopplersonografie (TCD)}

1. Den arteriellen Blutdruck messen: arterieller Mitteldruck bei Erwachsenen $>60 \mathrm{mmHg}$, bei Kindern siehe $\bullet$ Tab. 2 .

2. 2-MHz-Sonde verwenden.

3. Mit hoher Sende- und Empfangsleistung beginnen, da sonst Signale mit schwacher Intensität nicht erfasst werden können.

4. Die Hüllkurve ausschalten, da sie mehr verwirrt als nützt.

5. Den Wandfilter unter $50 \mathrm{~Hz}$ senken, da sonst z. B. systolische Spitzen ausgefiltert werden.

6. Das Messvolumen möglichst groß wählen ( $15 \mathrm{~mm}$ ).

7. Die Untersuchung in größerer Tiefe beginnen, da distale Äste der A. cerebri media komprimiert und verlagert sein können.

Transkranielle farbkodierte Duplexsonografie (TCCS)

1. Den arteriellen Blutdruck messen: arterieller Mitteldruck bei Erwachsenen $>60 \mathrm{mmHg}$, bei Kindern siehe $\mathbf{T a b} \mathbf{2}$

2. 1- bis 2,5-MHz-Sonde verwenden.

3. Farbfenster nicht zu groß einstellen.

4. Pulsrepetitionsfrequenz (PRF) für niedrige Flusssignale optimieren (reduzieren).

5. Farbgain (Empfangsleistung für den Farbmodus) erhöhen.

6. Korrekte Schallebenen auswählen, dabei anatomische Landmarken im B-Bild zum Aufsuchen der Gefäße nutzen: a) obere Ponsebene (Treffpunkt von Keilbeinflügel und Felsenbein) für ACI-Siphon und A. ophthalmica, b) untere Ponsebene (Felsenbein) für petrosale ACl, c) Mittelhirnebene für Darstellung der Circulus-Willisii-Ebene.

7. Bei fehlendem intrakraniellem Flusssignal, jedoch noch erkennbare Strukturen im B-Bild Gabe eines Echosignalverstärkers erwägen.

${ }^{1}$ Die Bildgebung erlaubt eine exakte topografische Zuordnung der Dopplersignale, die man für die Diagnose des Zirkulationsstillstands verwertet.

in der RL4-BÄK zur Vermeidung von irrtümlichen Gefäßzuordnungen bewusst in Kauf genommen. Auch in einem solchen Fall kann die CTA als alternatives Verfahren erwogen werden, da dort die Diagnose eines zerebralen Zirkulationsstillstands trotz eines residualen Flusses in der die A. ophthalmica versorgenden A. carotis interna zulässig ist [1, 50].

Gemäß den Vorgaben der RL4-BÄK ist neben dem Einsatz einer anderen Methode zum Nachweis des zerebralen Zirkulationsstillstands alternativ unter Beachtung der jeweils erforderlichen Voraussetzungen die Möglichkeit des Einsatzes einer elektrophysiologischen Methode oder der 2. klinischen Untersuchung nach entsprechender Wartezeit gegeben [1, 3].
Tab. 4 Fallstricke (modifiziert nach Günther et al. [45]).

Tab. 5 Untersuchungstechnik zum Nachweis des Zirkulationsstillstands.

\section{Danksagung}

\section{$\nabla$}

Die Autoren danken Prof. Dirk Droste (Centre Hospitalier de Luxembourg, Luxemburg), Doz. Dr. Christine Kremer (Lunds Universitet, Lund, Schweden), Prof. David Školoudík (Univerzita Palackého, Olmütz, Tschechische Republik), Dr. Françoise van de Wyngaert (Université catholique de Louvain, Brüssel, Belgien) und Dr. Paul A. von Weitzel-Mudersbach (Århus Universitetshospital, Aarhus, Dänemark) für hilfreiche Informationen.

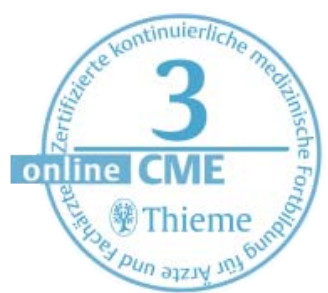


or duplex sonography as applicable), the results report (not necessarily the original image printouts) is archived for 30 years [1].

Procedure in the case of an incomplete examination or inconclusive findings

If the Doppler/duplex sonography examination cannot be completed according to the specifications of the German Medical Association's guidelines, it is possible to use an alternative method to determine cerebral circulatory arrest (contrastenhanced CTA, perfusion scintigraphy) [1]. This is also true in cases in which extra-intracranial shunt flows are detected by Doppler/duplex sonography. This constellation can be observed after secondary brain injury with no severe brain edema, no maximally increased intracranial pressure, and thus no cerebral circulatory arrest. Moreover, it is possible, although rare in practice, that the increase in cerebral necrosis results in partial disappearance of the Doppler/duplex sonographic signs of circulatory arrest (systolic spikes, biphasic flow signals) and in the recurrence of weak orthograde flows [48]. The diagnosis of circulatory arrest cannot be made via TCCS according to the German Medical Association's guidelines when the flow in the intracranial internal carotid artery in the direction of the ophthalmic artery is preserved even if typical flow signals (systolic spikes, biphasic flow signals) are detected bilaterally in the middle cerebral artery, anterior cerebral artery, posterior cerebral artery, basilar artery, and vertebral artery (V4 segment). This false-negative sonographic constellation of findings that is occasionally present in irreversible cessation of brain function [49] was consciously accepted in the German Medical Association's guidelines in order to avoid erroneous vessel assignments. Even in such a case, CTA can be considered as an alternative method since cerebral circulatory arrest can be diagnosed with this method despite a residual flow in the internal carotid artery supplying the ophthalmic artery $[1,50]$.

According to the specifications of the German Medical Association's guidelines, in addition to the use of another method to determine cerebral circulatory arrest, it is alternatively possible to use an electrophysiological method or second clinical examination after the proper waiting period in compliance with the respective requirements $[1,3]$.

\section{Acknowledgments}

The authors thank Prof. Dirk Droste (Centre Hospitalier de Luxembourg, Luxembourg), Doz. Dr. Christine Kremer (Lunds Universitet, Lund, Sweden), Prof. David Školoudík (Univerzita Palackého, Olomouc, Czech Republic), Dr. Françoise van de Wyngaert (Université catholique de Louvain, Brussels, Belgium) and Dr. Paul A. von WeitzelMudersbach (Århus Universitetshospital, Aarhus, Denmark) for helpful information.

\section{References}

1 Wissenschaftlicher Beirat der Bundesärztekammer. Richtlinie gemäß §16 Abs. 1 S. 1 Nr. 1 TPG für die Regeln zur Feststellung des Todes nach $\S 3$ Abs. $1 \mathrm{~S} .1 \mathrm{Nr}$. 2 TPG und die Verfahrensregeln zur Feststellung des endgültigen, nicht behebbaren Ausfalls der Gesamtfunktion des Großhirns, des Kleinhirns und des Hirnstamms nach §3 Abs. 2 Nr. 2 TPG, Vierte Fortschreibung. Dtsch Ärztebl 2015; 112: A-1256

2 Kaps $M$, Schreiber S, Walter U. Doppler- und Duplexsonografie in der Diagnostik des irreversiblen Hirnfunktionsausfalls. Klin Neurophysiol 2016; 47: 26 32

3 Walter U, Brandt SA, Ferbert A et al. Empfehlungen der Deutschen Gesellschaft für Klinische Neurophysiologie und Funktionelle Bildgebung zur Diagnostik des irreversiblen Hirnfunktionsausfalls. Klin Neurophysiol 2016; 47: 16-20

4 Wahlster S, Wijdicks EF, Patel PV et al. Brain death declaration: Practices and perceptions worldwide. Neurology 2015; 84: 1870-1879

5 Danish Health Agency. Bekendtgørelse om dødens konstatering ved uopretteligt ophør af al hjernefunktion, BEK nr 1249/2006., available at: http://www.organdonation.dk/om-organdonation/diagnosticeringaf-hjernedod

6 Swedish National Board. Föreskrifter och allmänna råd: Kriterier för bestämmande av människans död. SOSFS 2005: 10 (M)., available at: www.socialstyrelsen.se/Lists/Artikelkatalog/Attachments/9833/200510-10_2005_10.pdf

7 Orban JC, El-Mahjoub A, Rami L et al. Transcranial Doppler shortens the time between clinical brain death and angiographic confirmation: a randomized trial. Transplantation 2012; 94: 585-588

8 Orban JC, Ferret E, Jambou $P$ et al. Confirmation of brain death diagnosis: A study on French practice. Anaesth Crit Care Pain Med 2015; 34: 145-150

9 Vicenzini E, Pro S, Pulitano P et al. Current practice of brain death determination and use of confirmatory tests in an Italian University hospital: a report of 66 cases. Minerva Anestesiol 2013; 79: 485-491

10 Hoffmann 0 , Masuhr F. Zugang zur Hirntoddiagnostik. Nervenarzt 2014; 85: 1573-1581

11 Escudero D, Valentín MO, Escalante JL et al. Intensive care practices in brain death diagnosis and organ donation. Anaesthesia 2015; 70: 1130-1139

12 Consensus Group on Transcranial Doppler in Diagnosis of Brain Death. Latin American consensus on the use of transcranial Doppler in the diagnosis of brain death. Rev Bras Ter Intensiva 2014; 26: 240-252

13 Alexandrov AV, Sloan MA, Tegeler $\mathrm{CH}$ et al. Practice standards for transcranial Doppler (TCD) ultrasound. Part II. Clinical indications and expected outcomes. J Neuroimaging 2012; 22: 215-224

14 Ducrocq X, Hassler W, Moritake K et al. Consensus opinion on diagnosis of cerebral circulatory arrest using Doppler-sonography: Task Force Group on cerebral death of the Neurosonology Research Group of the World Federation of Neurology. J Neurol Sci 1998; 159: $145-150$

15 Ledoux $D$. Definition et diagnostic de la mort cerebrale. In: Monbaliu D, Lormans P, Ledoux D (Hsrg.) Livre de poche Don d'organes et de tissus. Leuven: Acco; 2014: 53-69

16 Henri, Grand-Duc de Luxembourg, Duc de Nassau, and Di Bartolomeo M, Le Ministre de la Santé. Règlement grand-ducal du 3 décembre 2009 déterminant les procédés à suivre pour constater la mort en vue d'un prélèvement. Journal Officiel du Grand-Duché de Luxembourg 2009: A: 4291, available at: http:// www.legilux.public.lu/rgl/2009/A/4291/B.pdf

17 Health Council of the Netherlands. Vaststellen van de dood bij postmortale orgaandonatie. Protocollen en criteria, inclusief een geactualiseerd Hersendoodpro- 
tocol. Den Haag: Health Council of the Netherlands, 2015; publication no. 2015/13

18 Österreichisches Bundesinstitut für Gesundheitswesen. Empfehlungen zur Durchführung der Hirntoddiagnostik bei einer geplanten Organentnahme entsprechend dem Beschluss des Obersten Sanitätsrates vom 16. November 2013., available at: http:/ www.austrotransplant.at/download/Empfehlungen_Hirntoddiagnostik.pdf

19 Ministry of Health of Poland. Obwieszczenie ministra zdrowia z dnia 17 lipca 2007r. w sprawie kryteriów i sposobu stwierdzenia trwałego nieodwracalnego ustania czynności mózgu. Monitor Polski 2007; 46: Pos. 547

20 Schweizerische Akademie der Medizinischen Wissenschaften. Feststellung des Todes mit Bezug auf Organtransplantationen. Medizinisch-ethische Richtlinien. Basel: Schweizerische Akademie der Medizinischen Wissenschaften; 2011

21 Ministry of Health of Czech Republic. Vyhláška ze dne 29. dubna 20130 stanovení bližších podmínek posuzování zdravotní způsobilosti a rozsahu vyšetření žijícího nebo zemřelého dárce tkání nebo orgánů pro účely transplantací (vyhláška o zdravotní způsobilosti dárce tkání a orgánů pro účely transplantací), 114/2013 Sb.., available at: https://portal.gov.cz/app/ zakony/zakonPar.jsp?idBiblio=79893\&nr=114 2F2013\&rpp=15\#local-content

22 Tomek A, Školoudík D, Škoda O et al. Metodika stanovení smrti mozku pomocí transkraniální sonografie vypracovaná Neurosonologickou komisí a Cerebrovaskulární sekcí České neurologické společnosti ČLS JEP. Cesk Slov Neurol N 2016, in press

23 Topcuoglu MA, Arsava EM, Bas DF et al. Transorbital Ultrasonographic Measurement of Optic Nerve Sheath Diameter in Brain Death. J Neuroimaging 2015; 25: 906-909

24 Welschehold S, Boor S, Reuland $K$ et al. Technical aids in the diagnosis of brain death: a comparison of SEP, AEP, EEG, TCD and CT angiography. Dtsch Arztebl Int 2012; 109: 624-630

25 von Reutern GM. Zerebraler Zirkulationsstillstand. Diagnostik mit der Dopplersonografie. Dtsch Ärztebl 1991; 88: A-4379-A-4385

26 Ducrocq X, Braun M, Debouverie $M$ et al. Brain death and transcranial Doppler: experience in 130 cases of brain dead patients. J Neurol Sci 1998; 160: $41-46$

27 Hadani M, Bruk B, Ram Z et al. Application of transcranial Doppler ultrasonography for the diagnosis of brain death. Intens Care Med 1999; 25: 822-828

28 de Freitas GR, André C. Sensitivity of transcranial Doppler for confirming brain death: a prospective study of 270 cases. Acta Neurol Scand 2006; 113: 426-432

29 Marinoni M, Alari F, Mastronardi $V$ et al. The relevance of early TCD monitoring in the intensive care units for the confirming of brain death diagnosis. Neurol Sci 2011; 32: 73-77

30 Poularas J, Karakitsos D, Kouraklis G et al. Comparison between transcranial color Doppler ultrasonography and angiography in the confirmation of brain death. Transplant Proc 2006; 38: 1213-1217

31 Haque IU, Zaritsky AL. Analysis of the evidence for the lower limit of systolic and mean arterial pressure in children. Pediatr Crit Care Med 2007; 8: 138-144

32 Jackson LV, Thalange NK, Cole TJ. Blood pressure centiles for Great Britain. Arch Dis Child 2007; 92: 298 303

33 Pucelikova T, Dangas G, Mehran R. Contrast-induced nephropathy. Catheter Cardiovasc Interv 2008; 71: $62-72$

34 Lovrencic-Huzjan A, Vukovic V, Gopcevic A et al. Transcranial Doppler in brain death confirmation in clinical practice. Ultraschall in Med 2011; 32: 62-66
35 Kaps M, von Reutern GM, Stolz E et al. Ultraschall in der Neurologie. 2. korrigierte Auflage. Stuttgart: Georg Thieme Verlag; 2005

36 Kuo JR, Chen CF, Chio CC et al. Time dependent validity in the diagnosis of brain death using transcranial Doppler sonography. J Neurol Neurosurg Psychiatry 2006; 77: 646-649

37 Nedelmann M, Stolz E, Gerriets T et al. Consensus recommendations for transcranial color-coded duplex sonography for the assessment of intracranial arteries in clinical trials on acute stroke. Stroke 2009; 40: $3238-3244$

38 Krejza J. Swiat M, Pawlak MA et al. Suitability of temporal bone acoustic window: conventional TCD versus transcranial color-coded duplex sonography. J Neuroimaging 2007; 17: $311-314$

39 Llompart-Pou JA, Abadal JM, Velasco J et al. Contrastenhanced transcranial color sonography in the diagnosis of cerebral circulatory arrest. Transplant Proc 2009; 41: 1466-1468

40 Welschehold S, Geisel F, Beyer C et al. Contrast-enhanced transcranial Doppler ultrasonography in the diagnosis of brain death. J Neurol Neurosurg Psychiatry 2013; 84: 939-940

41 Piscaglia F, Nolsøe C, Dietrich CF et al. The EFSUMB Guidelines and Recommendations on the Clinical Practice of Contrast Enhanced Ultrasound (CEUS): update 2011 on non-hepatic applications. Ultraschall in Med 2012; 33: 33 - 59

42 Hassler W, Steinmetz H, Pirschel J. Transcranial Doppler study of intracranial circulatory arrest. J Neurosurg 1989; 71: 195-201

43 Poularas J, Karakitsos D, Kouraklis G et al. Comparison between transcranial color Doppler ultrasonography and angiography in the confirmation of brain death. Transplant Proc 2006; 38: 1213-1217

44 Harrer JU, Eyding J, Ritter $M$ et al. Neurosonografie in der neurologischen Notfall- und Intensivmedizin: Monitoring des erhöhten intrakraniellen Druckes, Hirntoddiagnostik und Untersuchung der zerebralen Autoregulation - Teil 2. Ultraschall in Med 2012; 33: $320-331$

45 Günther A, Llompart-Pou JA, Klingner C et al. Sonografische Methoden in der Hirntoddiagnostik. Klin Neurophysiol 2014; 45: 168-175

46 Brandt SA, Walter U, Schreiber SJ. Anwendung der aktuellen Richtlinie zur Feststellung des irreversiblen Hirnfunktionsausfalls. Akt Neurol 2016; 43: $182-$ 203

47 Chang JJ, Tsivgoulis G, Katsanos AH et al. Diagnostic Accuracy of Transcranial Doppler for Brain Death Confirmation: Systematic Review and Meta-Analysis. AJNR Am J Neuroradiol 2016; 37: 408-414

48 Burger R, Schlake HP, Seybold S et al. Die Wertigkeit der transkraniellen Dopplersonografie im Vergleich zu szintigrafischen Verfahren und EEG in der Hirntoddiagnostik. Zentralbl Neurochir 2000; 61: 7-13

49 Azevedo E, Teixeira J, Neves JC et al. Transcranial Doppler and brain death. Transplant Proc 2000; 32: $2579-2581$

50 Lanfermann $H$, Schober $O$. Imaging of Irreversible Loss of Brain Function. Fortschr Röntgenstr 2016; 188: $23-26$

Bitte beachten Sie, dass die VNR-Nummer geänder wurde. Die richtige VNR-Nummer lautet: 2760512017152371045

Please note, the VNR number was changed. The new VNR number is VNR 2760512017152371045

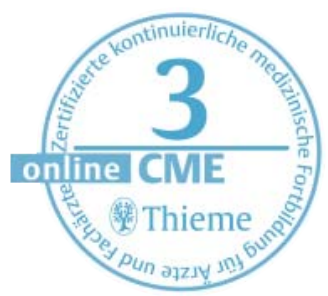




\section{CME-Questions Doppler and Duplex Sonography for the Diagnosis of the Irreversible Cessation of Brain Function ("Brain Death"): Current Guidelines in Germany and Neighboring Countries}

1

Which artery is an obligatory part of the sonographic examination protocol in all countries in which sonography of brain-supplying vessels is approved for the diagnosis of cerebral circulatory arrest?

A internal carotid artery (bilaterally)

B middle cerebral artery (bilaterally)

C posterior cerebral artery (bilaterally)

D vertebral artery (bilaterally)

E basilar artery

Which of the following statements is incorrect? The following measures are suitable for improving the detection of flow signals with transcranial Doppler sonography: system parameter settings: wall filter (high-pass filter) $\leq 50 \mathrm{~Hz}$

B system parameter settings: high receiver gain

C start of investigation at shallow depth

D choice of the correct insonation planes

E use of ultrasound contrast agents

Which flow signals are present in the basal brain arteries in the case of cerebral circulatory arrest?

biphasic flow signals (oscillating flow signals) with equally sized integral of the anterograde and the retrograde flow component

B early systolic spikes that are smaller than $50 \mathrm{~cm} / \mathrm{s}$ and last less than $200 \mathrm{~ms}$, with no other flow signal being able to be detected in the remaining cardiac cycle

c missing flow signals on transcranial sonography of basal brain arteries provided that the same investigator has documented definite intracranial flow signals in an earlier investigation of the same individual using the same ultrasound machine with the same system settings

D A and $\mathrm{B}$ are possible but not $\mathrm{C}$

E $\quad \mathrm{A}, \mathrm{B}$ and $\mathrm{C}$ are possible

Which of the following conditions is a prerequisite for the use of sonography of brain-supplying vessels for the diagnosis of brain death?

A In adults the mean arterial pressure needs to be higher than $60 \mathrm{~mm} \mathrm{Hg}$.

B The mean arterial pressure needs to be lower than $160 \mathrm{~mm}$ $\mathrm{Hg}$.

C Any potential effect of sedating medication has to be completely ruled out.

D Primarily supratentorial brain damage has to be present.

E The age of the patient must not be lower than 2 years.
Which of the following statements is incorrect? For the determination of cerebral circulatory arrest ... sonography of the brain-supplying arteries must be repeated after a waiting period of at least 30 minutes.

B it is possible to switch to an alternative neuroimaging method for the determination of cerebral circulatory arrest if the findings of Doppler sonography are inconclusive.

C transorbital sonography of optic nerve sheath is not suitable.

D sonography is approved in all European countries.

E sonography of brain-supplying arteries can be applied irrespective of the patient's age.

Which of the following statements is incorrect? According to the German guidelines, the determination of cerebral circulatory arrest using Doppler/duplex sonography ...

A can be performed irrespective of the type of brain damage.

B is obligatory in the case of secondary brain injury.

C precludes all potentially reversible causes of the clinical signs of brain death.

D needs to be performed after each of the two obligatory clinical brain death protocols in children who are younger than 2 years.

E can be performed for the brain death protocol only after documentation of the clinical signs of loss of brain function.

Despite the presence of flow signals characteristic for circulatory arrest in all basal brain arteries to be examined, the diagnosis of cerebral circulatory arrest cannot be made with Doppler sonography if ...

A the core body temperature was $34^{\circ} \mathrm{C}\left(93^{\circ} \mathrm{F}\right)$ during the examination.

B the electroencephalogram acquired 24 hours earlier showed some brain activity.

c on Doppler sonography arteriovenous shunt flow was additionally detected at the skull base.

D the mean arterial blood pressure was $80 \mathrm{~mm} \mathrm{Hg}$ during the examination.

E the preceding determination of the clinical signs of brain death could not be completely performed due to injury of the patient's eyes. 
8 Which of the following statements is incorrect? The determination of cerebral circulatory arrest using Doppler or duplex sonography...

A requires a probe specifically developed for brain death diagnostics.

B requires the bilateral examination of twin brain-supplying arteries.

C requires a physician with sufficient experience with this specific diagnostic application of sonography.

D does not replace the determination of the clinical signs of brain death if they are assessable.

E is only successful if the intracranial pressure is greater than the mean arterial blood pressure.

9 After the determination of the clinical signs of brain death, the development of the sonographically detectable flow signals in the brain-supplying arteries that are characteristic for cerebral circulatory arrest ...

A is always completed within 6 hours.

B can be expected in children younger than 2 years in every case.

C is rarely present after secondary brain injury.

D can only be shown with transcranial insonation.

E can last 24-36 hours in some cases.
Which of the following statements is correct?

A Primarily missing flow signals on transcranial sonography can be interpreted as proof of cerebral circulatory arrest.

B Occasionally detected flow signals in the intracranial internal carotid artery towards the ophthalmic artery do not exclude the determination of cerebral circulatory arrest using Doppler or duplex sonography.

C If systolic spikes last more than $200 \mathrm{~ms}$ due to bradycardia, this can be interpreted as proof of cerebral circulatory arrest.

D Sinus tachycardia of $160 /$ min can simulate preserved flow in basal brain arteries (despite its absence) due to the overlap of Doppler pulse waves.

E In the case of a lack of a transtemporal acoustic window, it is sufficient to examine the vertebral arteries bilaterally and the basilar artery for the determination of cerebral circulatory arrest. 


\section{CME-Fragen Doppler- und Duplexsonografie in der Diagnostik des irreversiblen Hirnfunktionsausfalls („Hirntod“): Aktuelle Richtlinien in Deutschland und benachbarten Ländern}

1

Welche Arterie ist in allen Ländern, in denen die Sonografie zur Feststellung des zerebralen Zirkulationsstillstands zugelassen ist, obligater Bestandteil des sonografischen Untersuchungsprotokolls?

A A. carotis interna beidseits

B A. cerebri media beidseits

C A. cerebri posterior beidseits

D A. vertebralis beidseits

E A. basilaris

Welche Aussage trifft nicht zu? Zur Verbesserung der Detektion von Flusssignalen mittels der transkraniellen Dopplersonografie sind folgende Maßnahmen geeignet:

A Geräteeinstellung: Wandfilter $\leq 50 \mathrm{~Hz}$

B Geräteeinstellung: hohe Empfangsverstärkung

C Beginn der Untersuchung in kleiner Tiefe

D Auswahl der korrekten Schallebenen

E Verwendung von Ultraschall-Kontrastmitteln

Welche Strömungssignale der Hirnbasisarterien liegen bei zerebralem Zirkulationsstillstand vor?

A biphasische Strömungssignale (oszillierende Strömungssignale) mit gleich ausgeprägtem Integral der antero- und retrograden Komponente

B frühsystolische Spitzen, die kleiner als $50 \mathrm{~cm} / \mathrm{s}$ sind und unter 200 ms anhalten, wobei kein weiteres Strömungssignal im verbleibenden Herzzyklus detektierbar sein darf

c fehlende Strömungssignale bei transkranieller Sonografie der Hirnbasisarterien, wenn derselbe Untersucher mit gleicher Geräteeinstellung während einer früheren Untersuchung eindeutig ableitbare intrakranielle Strömungssignale dokumentiert hat

D A und B sind möglich, $C$ trifft nicht $z u$.

E A, B und $C$ sind möglich.

Welche Voraussetzung muss für den Einsatz der Sonografie hirnversorgender Arterien im Rahmen der Hirntoddiagnostik erfüllt sein?

A Bei Erwachsenen muss der arterielle Mitteldruck bei über $60 \mathrm{mmHg}$ liegen.

B Der arterielle Mitteldruck muss unter $160 \mathrm{mmHg}$ liegen.

C Eine Wirkung sedierender Medikamente muss vollständig ausgeschlossen sein.

D Es muss eine primär supratentorielle Hirnschädigung vorliegen.

E Das Alter des/der Untersuchten muss mindestens 2 Jahre sein.
5

A muss die Sonografie der hirnversorgenden Arterien im Abstand von mindestens 30 Minuten wiederholt werden.

B kann bei unsicherem Befund der Dopplersonografie ein alternatives Verfahren zur Feststellung des zerebralen Zirkulationsstillstands durchgeführt werden.

C ist die transorbitale Sonografie der Nervus-opticus-Scheide ungeeignet.

D ist die Sonografie in allen europäischen Ländern zugelassen.

E kann die Sonografie der hirnversorgenden Arterien in jedem Lebensalter eingesetzt werden.

6 Welche Aussage trifft nicht zu? Der Nachweis des zerebralen Zirkulationsstillstands mittels Doppler-/Duplexsonografie gemäß den in Deutschland geltenden Richtlinien ...

A kann bei allen Hirnschädigungen erfolgen.

B ist bei sekundärer Hirnschädigung obligatorisch.

C schließt potenziell reversible Ursachen der klinischen Symptome des Hirnfunktionsausfalls aus.

D muss im Falle ihres Einsatzes bei unter 2-jährigen Kindern nach jeder der beiden klinischen Untersuchungen durchgeführt werden.

E darf für das Protokoll erst nach der Erhebung der klinischen Symptome des Hirnfunktionsausfalls durchgeführt werden.

Trotz Vorliegens typischer Strömungssignale des Zirkulationsstillstands in allen zu untersuchenden Hirnbasisarterien kann mittels Dopplersonografie der zerebrale Zirkulationsstillstand nicht festgestellt werden, wenn ...

A die Körperkerntemperatur während der Untersuchung bei $34^{\circ} \mathrm{C}$ lag.

B das Elektroenzephalogramm 24 Stunden zuvor noch ein geringe Hirnaktivität zeigte.

c dopplersonografisch zusätzlich an der Hirnbasis ein arterio-venöser Shuntfluss nachgewiesen wurde.

D der arterielle Mitteldruck während der Untersuchung bei $80 \mathrm{mmHg}$ lag.

E die zuvor durchgeführte Erhebung der klinischen Symptome des Hirnfunktionsausfalls wegen Augenverletzung nur unvollständig möglich war. 
8 Welche Aussage trifft nicht zu? Die Feststellung des zerebralen Zirkulationsstillstands mittels Doppler-/Duplexsonografie ...

A bedarf einer speziell für die Hirntoddiagnostik entwickelten Sonde.

B erfordert immer die beidseitige Untersuchung der paarigen hirnversorgenden Arterien.

C muss von einem speziell in dieser Untersuchung erfahrenen Arzt durchgeführt werden.

D ersetzt nicht die Erhebung der klinischen Symptome des Hirnfunktionsausfalls, wenn diese untersuchbar sind.

E gelingt nur, wenn der intrakranielle Druck über dem mittleren arteriellen Blutdruck liegt.

Die Entwicklung der für den zerebralen Zirkulationsstillstand charakteristischen doppler-/duplexsonografischen Strömungssignale nach Feststellung der klinischen Symptome des Hirnfunktionsausfalls ...

A ist immer innerhalb von 6 Stunden abgeschlossen.

B ist bei Kindern unterhalb des 2. Lebensjahrs in allen Fällen zu erwarten.

C tritt selten bei sekundärer Hirnschädigung ein.

D kann ausschließlich mittels transkranieller Beschallung detektiert werden.

E kann in einigen Fällen 24-36 Stunden dauern.
10

Welche Aussage trifft zu?

A Primär fehlende Strömungssignale dürfen für sich allein als Nachweis des zerebralen Zirkulationsstillstands gewertet werden.

B Gelegentlich nachweisbare Flüsse in der intrakraniellen A. carotis interna in Richtung der A. ophthalmica sprechen nicht gegen die Feststellung des zerebralen Zirkulationsstillstands mittels Doppler-/Duplexsonografie.

C Wenn systolische Spitzen durch Bradykardie auf über 200 ms verlängert sind, dürfen sie als Beleg des zerebralen Zirkulationsstillstands gewertet werden.

D Eine Sinustachykardie von 160/min kann durch Überlagerung der Pulswellen eine noch vorhandene Strömung in Hirnbasisarterien vortäuschen.

E Bei fehlendem transtemporalem Schallfenster reicht die Untersuchung der beidseitigen A. vertebralis und der A. basilaris zur Feststellung des zerebralen Zirkulationsstillstands aus. 


\section{Continuing Medical Education (CME) - important note for readers outside Aus- tria, Germany and Switzerland $\nabla$}

At present, certification of the Continuing Medical Education features in Ultraschall in der Medizin/ European Journal of Ultrasound (UiM/EJU) is officially recognised by the German and Austrian medical associations and by the Swiss Ultrasound Society. Participants residing in other countries may please address their national medical association or their national specialist society for recognition of their CME scores.

Participation is possible via internet under http:// cme.thieme.com. For one Continuing Medical Education unit you will be credited with 3 score points. To be awarded this score, $70 \%$ of the questions must have been answered correctly. The $\mathrm{CME}$ unit in the present issue is available online for 12 months for CME participation.

CME participation for this article can be done online under http://cme.thieme.com.

\section{CME-Fortbildung mit Ultraschall in der Medizin}

Für Teilnehmer in Deutschland

Die Fortbildung in Ultraschall in der Medizin wurde von der Nordrheinischen Akademie für Ärztliche Fort- und Weiterbildung für das Fortbildungszertifikat anerkannt, das heißt, die Vergabe der Punkte kann direkt durch die Thieme Verlagsgruppe erfolgen. Die Fortbildung in Ultraschall in der Medizin gehört zur Kategorie „strukturierte interaktive Fortbildung“. Entsprechend einer Absprache der Ärztekammern werden die von der Nordrheinischen Akademie für Ärztliche Fort- und Weiterbildung anerkannten Fortbildungsveranstaltungen auch von den anderen zertifizierenden Ärztekammern anerkannt.

\section{Für Teilnehmer in Österreich}

Die Fortbildungspunkte der Ultraschall in der Medizin werden gemäß der Novellierung der DFPRichtlinien vom 23.6.2005 (§26 Abs.3) auch von den österreichischen Ärztekammern anerkannt.
Für Teilnehmer in der Schweiz

Die Fortbildungspunkte der Ultraschall in der Medizin werden gemäß der Richtlinien der SGUM/ SSUM anerkannt. Die Kontrolle der Fortbildung durch die SGUM/SSUM erfolgt im Auftrag der FMH (Foederation Medicorum Helveticorum) im Rahmen der Fortbildungsordnung.

\section{Datenschutz}

Ihre Daten werden ausschließlich für die Bearbeitung dieser Fortbildungseinheit verwendet. Es erfolgt keine Speicherung der Ergebnisse über die für die Bearbeitung der Fortbildungseinheit notwendige Zeit hinaus. Die Daten werden nach Versand der Testate anonymisiert. Namens- und Adressangaben dienen nur dem Versand der Testate. Die Angaben zur Person dienen nur statistischen Zwecken und werden von den Adressangaben getrennt and anonymisiert verarbeitet.

\section{Teilnahme}

Jede Ärztin und jeder Arzt soll das Fortbildungszertifikat erlangen können. Deshalb ist die Teilnahme am CME-Programm von Ultraschall in der Medizin nicht an ein Abonnement geknüpft! Die Teilnahme ist im Internet unter http://cme.thieme.de möglich. Im Internet muss man sich registrieren, wobei die Teilnahme an Fortbildungen abonnierter Zeitschriften ohne Zusatzkosten möglich ist. Die Fortbildungseinheit in diesem Heft ist 12 Monate online für eine CME-Teilnahme verfügbar.

\section{Teilnahmebedingungen}

Für eine Fortbildungseinheit erhalten Sie 3 Fortbildungspunkte im Rahmen des Fortbildungszertifikats. Hierfür müssen $70 \%$ der Fragen richtig beantwortet sein.

\section{CME-Fortbildung für Nicht-Abonnenten}

Teilnehmer, die nicht Abonnenten von Ultraschall in der Medizin sind, können für die Internet-Teilnahme dort direkt ein Guthaben einrichten, von dem pro Teilnahme ein Unkostenbeitrag abgebucht wird.

Die CME-Teilnahme für diesen Beitrag ist online möglich unter http://cme.thieme.de.
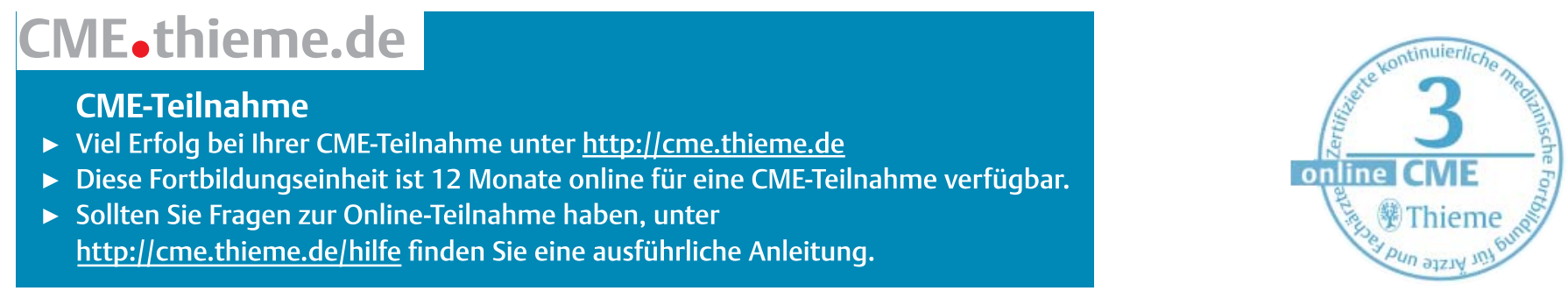